\title{
KATALOG PRAC LICENCJACKICH I MAGISTERSKICH WYDZIALU TEOLOGICZNEGO UNIWERSYTETU MIKOLAJA KOPERNIKA W TORUNIU Z LAT 2001-2010
}

W Archiwum Uniwersytetu Mikołaja Kopernika w Toruniu przechowywane są m.in. prace dyplomowe (licencjackie i magisterskie) powstałe na poszczególnych wydziałach. Autorka ${ }^{1}$ niniejszego zestawienia kontynuuje pracę rozpoczętą głównie przez dr Henrykę Duczkowską-Moraczewską ${ }^{2}$, kierownika Archiwum UMK w latach 1976-2010, choć pamiętać należy, że podobne wykazy sporządza-

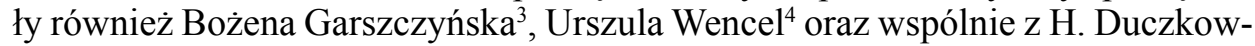
ską-Moraczewską, Ewa Talarczyk (obecnie Wiśniewska) i Elżbieta Talarczyk5

* Weronika Krajniak - mgr historii, dokumentalista w Archiwum Uniwersytetu Mikołaja Kopernika w Toruniu, e-mail: krajniak@umk.pl

${ }^{1}$ Autorka zestawiła także doktoraty Wydziału Teologicznego Uniwersytetu Mikołaja Kopernika w Toruniu z lat 2003-2010, które ukażą się w półroczniku „Archiwa Biblioteki i Muzea Kościelne", 106 (2016).

${ }^{2} \mathrm{H}$. Moraczewska, Bibliografia prac zwiazanych z tematyka pomorska powstatych na Wydziale Humanistycznym w latach 1967-1972, „Rocznik Toruński”, 9 (1974) s. 289-312.

${ }^{3}$ B. Garszczyńska, Bibliografia prac magisterskich, doktorskich i habilitacyjnych Wydziatu Humanistycznego UMK zwiazanych z tematyka pomorska (1945-marzec 1967), „Rocznik Toruński”, 2 (1967) s. 193-221; taż, Bibliografia prac magisterskich, doktorskich i habilitacyjnych Wydziatu Biologii i Nauk o Ziemi (Geografia) UMK zwiazanych z tematyka pomorska (1945-1967), „Rocznik Toruński”, 3 (1969) s. 187-206.

${ }^{4}$ U. Wencel-Kalembkowa, Prace magisterskie napisane pod kierunkiem pracowników Katedry Historii Polski i Powszechnej XIX i XX w. UMK, „Zeszyty Naukowe UMK. Historia”, 7 (1972) s. 119-142;

${ }^{5}$ H. Moraczewska, E. Talarczyk [Wiśniewska], Bibliografia prac magisterskich, doktorskich i habilitacyjnych Wydziału Biologii i Nauk o Ziemi (Biologia) za lata 1945-1978, „Acta Universitatis Nicolai Copernici. Nauki Matematyczno-Przyrodnicze. Biologia”, z. 23, 1980, s. 91-206; taż, Bibliografia prac magisterskich, doktorskich i habilitacyjnych Wydziału Biologii i Nauk o Ziemi (Geografia) za lata 1948-1980, „Acta Universitatis Nicolai Copernici. Nauki Matematyczno-Przyrodnicze. Geografia", z. 17, 1982, s. 161-229; Katalog prac magisterskich i licencjackich absolwentów archiwistyki w Toruniu z lat 1951-2010, (oprac. H. Duczkowska-Moraczewska, E. Talarczyk, 
Niniejszy katalog zawiera wykaz prac licencjackich i magisterskich Wydziału Teologicznego UMK przechowywanych w Archiwum Uniwersyteckim. Spis obejmuje lata 2001-2010. Lata poniższego katalogu, wynikają z faktu, iż Wydział Teologiczny został powołany do życia 1 stycznia $2001 \mathrm{r}^{6}$ oraz z przepisów kancelaryjno-archiwalnych obowiązujących w $\mathrm{UMK}^{7}$.

Katalog zawiera:

1. imię i nazwisko autora pracy dyplomowej,

2. tytuł pracy dyplomowej,

3. imię i nazwisko promotora,

4. imię i nazwisko recenzenta,

5. sygnaturę archiwalną.

Autorka nadała zestawieniu układ chronologiczno-alfabetyczny według daty rocznej egzaminu dyplomowego oraz nazwiska autora pracy w ramach danego roku. Dane zawarte w katalogu pochodzą z bazy USOSweb ${ }^{8}$, która na UMK funkcjonuje od 2005 r. Rekordy w niej są sukcesywnie uzupełniane i aktualizowane, dlatego zachowano obecne, wg stanu na rok 2015, stopnie naukowe promotorów i recenzentów. Zrezygnowano $\mathrm{z}$ powtarzania promotora jako recenzenta $\mathrm{w}$ punkcie 4.

Podsumowując, w latach 2001-2010 na Wydziale Teologicznym UMK zdano 490 egzaminów dyplomowych. Tabela 1, zawierająca dane dotyczące liczby wypromowanych studentów przez poszczególnych promotorów, wskazuje, że najwięcej prac napisano pod kierunkiem ks. dr hab. Janusza Gręźlikowskiego (54 prace), ks. dr hab. Jana Perszona (46 prac) oraz dr hab. Beaty Bilickiej (37 prac). Łączna liczba pracowników naukowych, pełniących funkcję promotora w latach 2001-2010 wynosi 40 osób. Natomiast tabela 2 najlepiej oddaje rozkład napisanych prac w poszczególnych latach. Najwięcej egzaminów dyplomowych zdano w 2004 r., aż 90, a tylko po jednym w latach 2001-2002. Tematyka prac jest bardzo różnorodna, od badań i krytycznej interpretacji utworów hagiograficznych oraz literatury katechetycznej, biografistykę, dzieje parafii, po aktualne problemy z życia Kościoła, związane z przemianami społecznymi, kulturowymi i politycznymi.

Tabela 1. Liczba wypromowanych studentów

\begin{tabular}{|c|l|c|}
\hline Lp. & \multicolumn{1}{|c|}{ Promotor } & Liczba wypromowanych studentów \\
\hline $\mathbf{1}$ & $\mathbf{2}$ & $\mathbf{3}$ \\
\hline 1 & ks. dr hab. Janusz Gręźlikowski & 54 \\
\hline 2 & ks. prof. dr hab. Jan Perszon & 46 \\
\hline
\end{tabular}

E. Wiśniewska) w: Dorobek naukowy i dydaktyczny toruńskiego ośrodka archiwistyki, red. H. Robótka, Torun 2011, s. 317-477.

${ }^{6}$ Uchwała nr 20 Senatu Uniwersytetu Mikołaja Kopernika w Toruniu z dnia 19 grudnia 2000 roku w sprawie utworzenia Wydziału Teologicznego oraz kierunku studiów „teologia”, „Biuletyn Prawny UMK", nr 8 z dnia 28 grudnia 2000 r. http://www.umk.pl/uczelnia/dokumenty/biuletyn/ prawo/?akcja=dokument\&typ=Uchwaly\&nr=20\&bp=8\&rok=2000 (dostęp: $25.04 .2015 \mathrm{r}$ ).

${ }^{7}$ Przepisy kancelaryjno-archiwalne, oprac. H. Duczkowska-Moraczewska, H. Robótka, Toruń 2004, ss. 116. Rozdział III $\S 22$ w/w przepisów mówi o 3-letnim przechowywaniu dokumentacji spraw załatwionych w komórce/jednostce prowadzącej sprawę.

${ }^{8}$ Uniwersytecki System Obsługi Studiów. 


\begin{tabular}{|c|c|c|}
\hline 1 & 2 & 3 \\
\hline 3 & dr hab. Beata Bilicka & 37 \\
\hline 4 & ks. prof. dr hab. Ireneusz Werbiński & 28 \\
\hline 5 & ks. prof. dr hab. Anastazy Nadolny & 23 \\
\hline 6 & ks. prof. dr hab. Mirosław Mróz & 23 \\
\hline 7 & ks. prof. dr hab. Jerzy Bagrowicz & 21 \\
\hline 8 & ks. dr Tomasz Tułodziecki & 19 \\
\hline 9 & ks. prof. dr hab. Dariusz Kotecki & 20 \\
\hline 10 & ks. dr hab. Jacek Szymański & 17 \\
\hline 11 & ks. dr hab. Zbigniew Wanat & 16 \\
\hline 12 & ks. prof. dr hab. Krzysztof Konecki & 14 \\
\hline 13 & ks. dr Krzysztof Lewandowski & 14 \\
\hline 14 & ks. dr hab. Stanisław Suwiński & 14 \\
\hline 15 & ks. dr hab. Krzysztof Krzemiński & 13 \\
\hline 16 & ks. dr Bogusław Kwiatkowski & 12 \\
\hline 17 & ks. dr hab. Marian Graczyk & 11 \\
\hline 18 & ks. dr hab. Witold Kujawski & 11 \\
\hline 19 & ks. dr hab. Daniel Brzeziński & 11 \\
\hline 20 & ks. dr hab. Tadeusz Lewandowski & 10 \\
\hline 21 & prof. dr hab. Marian Grabowski & 10 \\
\hline 22 & ks. dr hab. Tomasz Kaczmarek & 8 \\
\hline 23 & ks. dr hab. Wiesław Kraiński & 8 \\
\hline 24 & ks. dr hab. Wojciech Hanc & 7 \\
\hline 25 & ks. bp prof. dr hab. Zbigniew Kiernikowski & 6 \\
\hline 26 & ks. prof. dr hab. Czesław Rychlicki & 6 \\
\hline 27 & ks. dr hab. Zbigniew Zarembski & 6 \\
\hline 28 & ks. dr hab. Wiesław Łużyński & 4 \\
\hline 29 & ks. dr Stanisław Jankowski & 4 \\
\hline 30 & o. dr hab. Mieczysław Paczkowski & 3 \\
\hline 31 & ks. dr Artur Niemira & 3 \\
\hline 32 & dr Andrzej Lewandowski & 2 \\
\hline 33 & ks. prof. dr hab. Waldemar Chrostowski & 2 \\
\hline 34 & ks. dr Stanisław Ciarkowski & 2 \\
\hline 35 & ks. dr Roman Małecki & 1 \\
\hline 36 & ks. dr Mariusz Klimek & 1 \\
\hline 37 & ks. dr Marek Raszewski & 1 \\
\hline 38 & ks. prof. dr hab. Dariusz Zagórski & 1 \\
\hline 39 & o. dr Borys Soiński & 1 \\
\hline 40 & o. dr Piotr Szymański & 1 \\
\hline
\end{tabular}


Tabela 2. Liczba prac dyplomowych w poszczególnych latach

\begin{tabular}{|c|c|c|c|c|c|c|c|c|c|c|}
\hline $\begin{array}{c}\text { Rok egzaminu } \\
\text { dyplomowego }\end{array}$ & $\mathbf{2 0 0 1}$ & $\mathbf{2 0 0 2}$ & $\mathbf{2 0 0 3}$ & $\mathbf{2 0 0 4}$ & $\mathbf{2 0 0 5}$ & $\mathbf{2 0 0 6}$ & $\mathbf{2 0 0 7}$ & $\mathbf{2 0 0 8}$ & $\mathbf{2 0 0 9}$ & $\mathbf{2 0 1 0}$ \\
\hline Liczba prac & 1 & 1 & 26 & 90 & 56 & 53 & 77 & 72 & 61 & 53 \\
\hline
\end{tabular}

Z poniższych, niepublikowanych prac dyplomowych można skorzystać w pracowni naukowej Archiwum UMK. Prace udostępniane są do celów naukowo-badawczych, oświatowych i kulturalnych na miejscu w archiwum, na podstawie wniosku o udostępnienie i rewersu złożonego przez użytkownika. Studenci i doktoranci chcący skorzystać z prac powstałych do 2005 r. powinni uzyskać pisemną aprobatę swojego opiekuna naukowego. Pozostali użytkownicy pisemne poparcie wniosku przez swojego przełożonego lub kierownika instytucji, w której pracują. Natomiast prace dyplomowe powstałe po 2005 r. mogą być udostępniane tylko w wypadku, gdy autor udzielił UMK zgody na ich udostępnianie w Archiwum UMK. Także w tym przypadku udostępniane są na takich samych zasadach jak prace powstałe do 2005 r. Nauczyciele akademiccy, posiadający, co najmniej stopień naukowy doktora, wypełniają wniosek z prośbą o udostępnienie prac dyplomowych, nie wymagający zgody, w którym określają cel kwerendy ${ }^{9}$.

\title{
KATALOG PRAC DYPLOMOWYCH
}

\author{
2001
}

(1) Tomalak Andrzej (2) Nieśmiertelność czlowieka w polskiej literaturze teologicznej po II Soborze Watykańskim (3) ks. dr hab. Wojciech Hanc (4) ks. prof. dr hab. Ireneusz Werbiński (5) 163851

2002

(1) Bółkowski Krystian (2) Jakub Zadzik-biskup chetmiński i administrator diecezji pomezańskiej (1624-1635) (3) ks. prof. dr hab. Anastazy Nadolny (4) ks. dr hab. Witold Kujawski (5) 163240

\section{3}

(1) Adamski Marcin (2) Założenia liturgiczno-prawne dla przestrzeni celebracyjnej (3) ks. prof. dr hab. Krzysztof Konecki (4) ks. dr hab. Jacek Szymański (5) 163829

(1) Antonkiewicz Marcin (2) Synod biskupa Macieja Lubieńskiego z 1634 roku (3) ks. dr hab. Janusz Gręźlikowski (4) ks. prof. dr hab. Krzysztof Konecki (5) 163830

${ }^{9}$ Więcej informacji: Zarządzenie nr 75 Rektora Uniwersytetu Mikołaja Kopernika w Toruniu, z dnia 30 maja 2012 r. w sprawie udostępniania i korzystania z zasobu Archiwum UMK, http:// archiwum.umk.pl/zasob/regulamin/Z_Rektora_75_2012.pdf(dostęp: 25.04.2015). 
(1) Badach Wojciech (2) Didaskalos w ,Stromatach” Klemensa Aleksandryjskiego (3) ks. prof. dr hab. Anastazy Nadolny (4) prof. dr hab. Ireneusz Mikołajczyk (5) 163239

(1) Bartczak Tomasz (2) Formacja duchowa osób starszych w oparciu o nauczanie Jana Pawta II (3) ks. prof. dr hab. Ireneusz Werbiński (4) ks. prof. dr hab. Krzysztof Konecki (5) 163833

(1) Bogus Rafał (2) Aktualizacja kerygmatu czytań biblijnych XVI Niedzieli Zwykłej Roku C w kaznodziejstwie polskim w latach 1974-2001 (3) ks. dr hab. Tadeusz Lewandowski (4) ks. prof. dr hab. Krzysztof Konecki (5) 163834

(1) Ciechanowski Jarosław (2) Świeckość życia konsekrowanego na podstawie duchowości Instytutu Miłosierdzia Bożego (3) ks. prof. dr hab. Ireneusz Werbiński (4) ks. dr Krzysztof Lewandowski (5) 163242

(1) Dąbkowski Michał (2) Pastoralno-liturgiczny charakter obchodów Roku Jubileuszowego w Diecezji Toruńskiej na przykładzie kościołów stacyjnych (3) ks. dr Krzysztof Lewandowski (4) ks. prof. dr hab. Ireneusz Werbiński (5) 163243

(1) Deręgowski Sławomir (2) Aktualizacja kerygmatu czytań biblijnych IV Niedzieli Zwyktej Roku C w kaznodziejstwie polskim w latach 1974-2001 (3) ks. dr hab. Tadeusz Lewandowski (4) ks. prof. dr hab. Krzysztof Konecki (5) 163 835

(1) Drapała Dawid (2) Bigamia w ustawodawstwie Kościoła i wyrokach Sądu Biskupiego we Wloctawku w latach 1945-1988 (3) ks. dr hab. Janusz Gręźlikowski (4) ks. prof. dr hab. Krzysztof Konecki (5) 163836

(1) Duczmański Przemysław (2) Problem aborcji w świetle encykliki Jana Pawła II „Evangelium vitae” (3) ks. dr hab. Jacek Szymański (4) ks. dr hab. Janusz Gręźlikowski (5) 163837

(1) Gmuczyk Zbigniew (2) Wolność człowieka a Prawo Boże w świetle encykliki „Veritatis splendor” (3) ks. dr hab. Jacek Szymański (4) ks. prof. dr hab. Ireneusz Werbiński (5) 163839

(1) Grajkowski Czesław (2) Parafia p.w. Św. Mikołaja w Chetmży w latach 19451998 (3) ks. prof. dr hab. Anastazy Nadolny (4) ks. dr hab. Witold Kujawski (5) 163244

(1) Janowski Jarosław (2) Przesłanie markowej perykopy o przemienieniu Jezusa (Mk 9,2-10) w polskiej posoborowej literaturze kaznodziejskiej. Studium egzegetyczno-homiletyczne (3) ks. prof. dr hab. Dariusz Kotecki (4) ks. bp prof. dr hab. Zbigniew Kiernikowski (5) 163245

(1) Jasiński Maciej (2) Homoseksualizm jako akt ptciowy wykluczajacy dar życia w świetle „, Katechizmu Kościoła Katolickiego” (3) ks. dr hab. Jacek Szymański (4) ks. prof. dr hab. Krzysztof Konecki (5) 163840

(1) Kejna Krzysztof (2) Wplyw życia duchowego na działalność apostolska Św. Jana Bosco (3) ks. prof. dr hab. Ireneusz Werbiński (4) ks. dr Krzysztof Lewandowski (5) 163246

(1) Kowalski Andrzej (2) Nowa ewangelizacja w świetle przemówień Jana Pawta II do biskupów polskich z okazji wizyt ,,ad limina apostorum " w latach 1969- 
1998 (3) dr Andrzej Lewandowski (4) ks. prof. dr hab. Ireneusz Werbiński (5) 163247

(1) Michalski Marek (2) Odkrywanie drogi powołania kapłańskiego jako daru i zadania w świetle nauki teologicznej (3) ks. prof. dr hab. Ireneusz Werbiński (4) ks. prof. dr hab. Krzysztof Konecki (5) 163844

(1) Morzycki Wojciech (2) Aktualizacja kerygmatu czytań biblijnych V Niedzieli Zwyktej Roku C w kaznodziejstwie polskim w latach 1974-2001 (3) ks. dr hab. Tadeusz Lewandowski (4) ks. prof. dr hab. Krzysztof Konecki (5) 163845

(1) Nowicki Grzegorz (2) Zagrożenia i szanse duchowe wspótczesnej młodzieży w oparciu o literature przedmiotu (3) ks. prof. dr hab. Ireneusz Werbiński (4) ks. prof. dr hab. Krzysztof Konecki (5) 163846

(1) Piasecki Jarosław (2) Dziewiczo-duchowe macierzyństwo Maryi w polskiej literaturze teologicznej po II Soborze Watykańskim (3) ks. dr hab. Wojciech Hanc (4) ks. prof. dr hab. Ireneusz Werbiński (5) 163848

(1) Roszak Piotr (2) Tajemnica ludzkiego oczekiwania. Aktualność nauki Św. Tomasza z Akwinu o cnocie nadziei w świetle „Sumy Teologii II-II”, qq. 17-22 (3) ks. prof. dr hab. Mirosław Mróz (4) ks. dr hab. Marian Graczyk (5) 163 248

(1) Skopiński Karol (2) Przymus i bojaźń w wyrokach sąu kościelnego diecezji włocławskiej w latach 1962-1966 (3) ks. dr hab. Janusz Gręźlikowski (4) ks. prof. dr hab. Krzysztof Konecki (5) 163849

(1) Stankowski Jerzy (2) Gtosiciel stowa bożego-stuga Boga i czlowieka w świetle pism św. Franciszka z Asyżu (3) ks. prof. dr hab. Jerzy Bagrowicz (4) ks. dr hab. Tadeusz Lewandowski (5) 163850

(1) Stasiak Mariusz (2) Orędzie perykopy Mk 3, 20-35 w polskiej literaturze kaznodziejskiej z lat 1974-2000. Studium egzegetyczno-homiletyczne (3) ks. prof. dr hab. Dariusz Kotecki (4) ks. bp prof. dr hab. Zbigniew Kiernikowski (5) 163249

(1) Zaworski Marcin (2) Rzeczywistość chrystusowego odkupienia w polskiej literaturze teologicznej po II Soborze Watykańskim (3) ks. dr hab. Wojciech Hanc (4) ks. prof. dr hab. Ireneusz Werbiński (5) 163852

(1) Zieliński Marek (2) Kościót światynia Ducha Świętego w polskiej literaturze teologicznej po II Soborze Watykańskim (3) ks. dr hab. Wojciech Hanc (4) ks. prof. dr hab. Ireneusz Werbiński (5) 163853

\section{4}

(1) Adamiak Stanisław (2) Ogniem posoleni. Studium egzegetyczne Mk 9, 49 (3) ks. prof. dr hab. Dariusz Kotecki (4) ks. bp prof. dr hab. Zbigniew Kiernikowski (5) 163228

(1) Bakiera-Błaszczyk Marzena (2) Wspólnota matżeńsko-rodzinna środowiskiem wychowania do odpowiedzialności moralnej w nauczaniu Jana Pawła II w Roku Rodzin (3) ks. dr hab. Marian Graczyk (4) ks. dr hab. Zbigniew Wanat (5) 169713

(1) Budkiewicz Mariusz (2) Aktualizacja kerygmatu czytań biblijnych uroczystości Jezusa Chrystusa, króla wszechświata Roku C w kaznodziejstwie polskim 
w latach 1974-2001 (3) ks. dr hab. Tadeusz Lewandowski (4) ks. prof. dr hab. Krzysztof Konecki (5) 163813

(1) Bułakowski Damian (2) Duchowość kapłańska „Listów wielkoczwartkowych” Jana Pawła II do kaptanów (3) ks. prof. dr hab. Ireneusz Werbiński (4) ks. prof. dr hab. Krzysztof Konecki (5) 163814

(1) Bydowska Iwona (2) Personalistyczne znamie koncepcji pedagogicznej ojca Józefa Kentenicha. Studium teologiczno-moralne (3) ks. dr hab. Marian Graczyk (4) ks. dr hab. Zbigniew Wanat (5) 169715

(1) Chodowska-Zacharek Dagmara (2) Magdalena Mortęska reformatorka klasztoru Benedyktynek w Chetmnie (3) ks. dr hab. Witold Kujawski (4) ks. dr hab. Wojciech Frątczak (5) 169716

(1) Dankowska Maria (2) Odpowiedzialność za poszanowanie świata w oparciu o wzór św. Franciszka z Asyżu w świetle wczesnych źródet franciszkańskich (3) ks. dr hab. Marian Graczyk (4) ks. dr hab. Zbigniew Wanat (5) 169717

(1) Długosz Aleksandra (2) Zarys dziejów parafii w Dźwierzchnie (3) ks. dr hab. Witold Kujawski (4) ks. dr hab. Wojciech Frątczak (5) 169718

(1) Dobry Maria (2) Maryja w tajemnicy Trójcy Świętej na podstawie „Kazań Maryjnych" Jana Pawta II (3) ks. prof. dr hab. Jan Perszon (4) ks. dr hab. Krzysztof Krzemiński (5) 169719

(1) Domin-Meler Justyna (2) Rodzina chrześcijańska środowiskiem wychowania moralnego dziecka. Studium teologicznomoralne (3) ks. dr hab. Zbigniew Wanat (4) ks. dr hab. Marian Graczyk (5) 169720

(1) Dydo Małgorzata (2) Wspótpraca katechety z rodzina i parafia w świetle posoborowych dokumentów katechetycznych Kościoła katolickiego w Polsce (3) dr hab. Beata Bilicka (4) ks. prof. dr hab. Dariusz Kotecki (5) 169721

(1) Dzieszka Małgorzata (2) Powołanie kobiety do życia rodzinnego w świetle nauczania Jana Pawła II a obraz kobiecości w wybranych podręcznikach przygotowania do życia w rodzinie (3) ks. prof. dr hab. Jan Perszon (4) ks. dr hab. Zbigniew Wanat (5) 169722

(1) Figiel Marcin (2) Sakrament bierzmowania w świetle uchwat drugiego synodu diecezji włocławskiej z 1994 roku (3) ks. dr hab. Janusz Gręźlikowski (4) ks. dr hab. Wojciech Hanc (5) 163815

(1) Funk Tadeusz (2) Sakrament chrztu w świetle uchwat drugiego synodu diecezji włocławskiej z 1994 roku (3) ks. dr hab. Janusz Gręźlikowski (4) ks. dr hab. Wojciech Hanc (5) 163816

(1) Gembicka Mariola (2) Rola muzyki kościelnej w formacji moralnej człowieka na podstawie literatury przedmiotu (3) ks. dr hab. Marian Graczyk (4) ks. dr hab. Zbigniew Wanat (5) 169723

(1) Grabowski Maciej (2) Obecność świeckich $w$ życiu parafii $w$ świetle II Polskiego Synodu Plenarnego (1991-1999) (3) ks. dr Krzysztof Lewandowski (4) ks. dr hab. Janusz Gręźlikowski (5) 163230

(1) Gurzyńska Urszula (2) Postuga miłosierdzia w kościele w świetle dokumentów II Polskiego Synodu Plenarnego (3) ks. dr hab. Zbigniew Wanat (4) ks. prof. dr hab. Mirosław Mróz (5) 169724 
(1) Idzikowski Marcin (2) Wplyw pornografii na czlowieka w okresie dojrzewania $w$ świetle dokumentu „Pornografia i przemoc w środkach spolecznego przekazu-odpowiedź duszpasterska" (3) ks. dr hab. Jacek Szymański (4) ks. prof. dr hab. Krzysztof Konecki (5) 163817

(1) Jackowska Lidia (2) Katecheza rodzinna $w$ procesie wychowania religijnego dzieci upośledzonych umystowo (3) dr hab. Beata Bilicka (4) ks. prof. dr hab. Dariusz Kotecki (5) 169726

(1) Janke Jolanta (2) Trudności wychowawcze wieku dorastania w oparciu o podręczniki pedagogiczne i katechetyczne (3) ks. prof. dr hab. Jan Perszon (4) ks. dr hab. Zbigniew Wanat (5) 169727

(1) Jankowska Danuta (2) Sens ludzkiej ptciowości w podręcznikach wychowania do życia w rodzinie (3) ks. prof. dr hab. Jan Perszon (4) ks. prof. dr hab. Mirosław Mróz (5) 169728

(1) Jaskulski Andrzej (2) Katecheza Jana Pawła II do młodzieży podczas pielgrzymek do Polski w latach 1979-2002 (3) dr hab. Beata Bilicka (4) ks. prof. dr hab. Dariusz Kotecki (5) 169729

(1) Jerzyńska Iwona (2) Katecheza szkolna po roku 1990 dzieci z głębsza niepetnosprawnościa intelektualna (3) dr hab. Beata Bilicka (4) ks. prof. dr hab. Dariusz Kotecki (5) 169730

(1) Joniec Arkadiusz (2) Odnowa liturgiczna obrzędów święceń biskupich (3) ks. prof. dr hab. Krzysztof Konecki (4) ks. dr hab. Jacek Szymański (5) 163841

(1) Jonik Wojciech (2) Obecność i dziatanie Szatana w świetle Listów o. Pio (3) ks. dr hab. Krzysztof Krzemiński (4) ks. prof. dr hab. Czesław Rychlicki (5) 163231

(1) Kaczmarek Ilona (2) Udziat świeckich $w$ katechezie i duszpasterstwie parafialnym w oparciu o dokumenty II Synodu Plenarnego Kościoła lokalnego (3) ks. prof. dr hab. Jan Perszon (4) ks. prof. dr hab. Mirosław Mróz (5) 169731

(1) Kalinowska Anna (2) Dzieje parafii pod wezwaniem św. Mikołaja w Papowie Biskupim (3) ks. dr hab. Witold Kujawski (4) ks. dr hab. Wojciech Frątczak (5) 169732

(1) Kejna Arkadiusz (2) Troska o pokój w świetle orędzi Jana Pawta II na Światowe Dni Pokoju (3) ks. dr hab. Zbigniew Wanat (4) ks. dr hab. Marian Graczyk (5) 169733

(1) Kierzkowski Mateusz (2) Elementy formalne w kaznodziejstwie w świetle polskiej literatury II połowy XX wieku (3) ks. dr hab. Tadeusz Lewandowski (4) ks. prof. dr hab. Krzysztof Konecki (5) 163818

(1) Kopczyńska Marzena (2) Rodzina szkoła modlitwy chrześcijańskiej (3) ks. dr hab. Zbigniew Wanat (4) ks. prof. dr hab. Mirosław Mróz (5) 169734

(1) Kopiec Teresa (2) Katecheza dorostych w świetle „Dyrektorium katechetycznego Kościoła katolickiego w Polsce” (3) dr hab. Beata Bilicka (4) ks. prof. dr hab. Dariusz Kotecki (5) 169735

(1) Kowalska Aneta (2) Maryja wzorem kobiety w Kościele w świetle nauczania Jana Pawta II (3) ks. dr Krzysztof Lewandowski (4) ks. prof. dr hab. Ireneusz Werbiński (5) 169736 
(1) Kowalski Dariusz (2) Sapientia cordis w nauczaniu św. Tomasza z Akwinu w świetle traktatów o uczuciach (3) ks. prof. dr hab. Mirosław Mróz (4) ks. dr hab. Marian Graczyk (5) 163232

(1) Kowalski Piotr (2) Sakrament pokuty i pojednania w świetle uchwat drugiego synodu diecezji włoctawskiej z 1994 roku (3) ks. dr hab. Janusz Gręźlikowski (4) ks. dr hab. Wojciech Hanc (5) 163819

(1) Krzemień Barbara (2) Teologiczno-fundamentalna weryfikacja mariofanii w Lourdes (3) ks. prof. dr hab. Jan Perszon (4) ks. dr hab. Krzysztof Krzemiński (5) 169737

(1) Krzysiak Krystyna (2) Rodzina u podstaw formacji do świętości w nauczaniu Jana Pawta II (1978-1998) (3) ks. dr hab. Marian Graczyk (4) ks. dr hab. Zbigniew Wanat (5) 169738

(1) Kuczyński Adam (2) Troska o człowieka pracy w świetle wypowiedzi Jana Pawta II (3) ks. dr hab. Zbigniew Wanat (4) ks. dr hab. Marian Graczyk (5) 169739

(1) Kuźniewska Janina (2) Teologiczna weryfikacja objawień fatimskich (3) ks. prof. dr hab. Jan Perszon (4) ks. dr hab. Krzysztof Krzemiński (5) 169740

(1) Kwiatkowski Jarosław (2) Duszpasterstwo rodzin w Archidiecezji Gnieźnieńskiej w świetle Dyrektorium Duszpasterstwa Rodzin (3) ks. dr Krzysztof Lewandowski (4) ks. prof. dr hab. Ireneusz Werbiński (5) 169741

(1) Lamparska Hanna (2) Moralne przestanie katechez Jana Pawła II poświęconych Matce Bożej (3) ks. dr hab. Zbigniew Wanat (4) ks. dr hab. Marian Graczyk (5) 169742

(1) Lange Mirosław (2) Internet jako środek formacji moralnej. Studium teologicznomoralne (3) ks. dr hab. Zbigniew Wanat (4) ks. dr hab. Marian Graczyk (5) 169743

(1) Lewandowska Katarzyna (2) Narkomania w Polsce jako problem pastoralny (3) ks. dr Krzysztof Lewandowski (4) ks. prof. dr hab. Ireneusz Werbiński (5) 169744

(1) Lisiński Marcin (2) Homo agitur a Spiritu Deo. Aktualność nauk św. Tomasza z Akwinu o darach Ducha Św. w świetle ,Summa Theologiae” I-II, q. 68 i II-II, qq. 8-9, 19, 45, 52, 121, 139 (3) ks. prof. dr hab. Mirosław Mróz (4) ks. dr hab. Marian Graczyk (5) 163233

(1) Lubkowska Barbara (2) Chrystocentryzm chrześcijańskiej egzystencji wedtug św. Teresy od Dzieciatka Jezus, doktora Kościoła (3) ks. prof. dr hab. Jan Perszon (4) ks. prof. dr hab. Mirosław Mróz (5) 169745

(1) Małecki Janusz (2) Obecność i działanie Ducha Świętego w nowych modlitwach eucharystycznych (3) ks. prof. dr hab. Krzysztof Konecki (4) ks. prof. dr hab. Ireneusz Werbiński (5) 163820

(1) Małecki Piotr (2) Obraz biskupa wedtug świadectw ojców apostolskich (3) ks. dr hab. Tomasz Kaczmarek (4) ks. dr hab. Witold Kujawski (5) 163821

(1) Mandra Zofia (2) Aspekty pastoralne sakramentu pokuty i pojednania w świetle Adhortacji Apostolskiej Jana Pawta II „Reconciliatio et paenitentia” (3) ks. dr Krzysztof Lewandowski (4) ks. prof. dr hab. Ireneusz Werbiński (5) 169746 
(1) Marach Aleksandra (2) Troska Kościoła o wtaściwe korzystanie ze środków społecznego przekazu w świetle II polskiego synodu plenarnego (3) ks. dr Krzysztof Lewandowski (4) ks. prof. dr hab. Ireneusz Werbiński (5) 169747

(1) Mądra Wiesława (2) Zastosowanie środków audiowizualnych $w$ katechezie szkolnej ze szczególnym uwzględnieniem wideo i komputera (3) dr hab. Beata Bilicka (4) ks. prof. dr hab. Dariusz Kotecki (5) 169748

(1) Morawiec Maria (2) Z dziejów parafii św. Mikołaja i św. Konstancji w Gniewkowie (3) ks. dr hab. Witold Kujawski (4) ks. dr hab. Wojciech Frątczak (5) 176311

(1) Nehring Dorota (2) Zadania rodziny chrześcijańskiej w świetle wypowiedzi Jana Pawła II do rodzin (3) ks. dr hab. Zbigniew Wanat (4) ks. prof. dr hab. Mirosław Mróz (5) 169749

(1) Nowacka Maria (2) Rozwój wiary w rodzinie w świetle wypowiedzi Jana Pawta II podczas pielgrzymek do ojczyzny (3) ks. dr hab. Zbigniew Wanat (4) ks. dr hab. Marian Graczyk (5) 169750

(1) Nowak Iwona (2) Duszpasterska troska a spoleczny lad pracy w świetle encykliki Jana Pawata II ,Laborem exercens” (3) ks. dr Krzysztof Lewandowski (4) ks. prof. dr hab. Ireneusz Werbiński, (5) 169751

(1) Nowak Róża (2) Sumienie w nauczaniu Jana Pawła II w świetle pielgrzymek do Polski (3) ks. dr hab. Marian Graczyk (4) ks. dr hab. Zbigniew Wanat (5) 169752

(1) Nowicka Sabina (2) Przygotowanie katechetyczne dzieci specjalnej troski do przyjęcia sakramentu pojednania i pokuty, eucharystii i bierzmowania (3) dr Andrzej Lewandowski (4) ks. prof. dr hab. Ireneusz Werbiński (5) 169713

(1) Olsztyńska Irena (2) Nauczania metodami gier dydaktycznych w katechezie gimnazjalnej w świetle programu , $W$ drodze do Ojca” "pod red. ks. T. Śmiecha (3) dr hab. Beata Bilicka (4) ks. prof. dr hab. Dariusz Kotecki (5) 169754

(1) Osiński Sebastian (2) Obrzęd błogosławieństwa narzeczonych w liturgii Kościoła domowego (3) ks. prof. dr hab. Krzysztof Konecki (4) ks. dr hab. Jacek Szymański (5) 163823

(1) Paczkowski Krzysztof (2) Wyzwania moralne dla katolików świeckich w świetle „Noty doktrynalnej dotyczacej pewnych kwestii zwiazanych z udziatem $i$ postawa katolików $w$ życiu politycznym”, kongregacji nauki wiary z 24 listopada 2002 roku (3) ks. dr hab. Marian Graczyk (4) ks. dr hab. Zbigniew Wanat (5) 169755

(1) Piasecka Beata (2) Chrześcijanin wobec życia w świetle encykliki „Evangelum vitae" Jana Pawta II (3) ks. dr hab. Marian Graczyk (4) ks. dr hab. Zbigniew Wanat (5) 169756

(1) Przeracka Barbara (2) Chrystocentryzm modlitwy różańcowej w oparciu o list apostolski , Rosarium virginis mariae” Jana Pawła II (3) ks. prof. dr hab. Jan Perszon (4) ks. prof. dr hab. Mirosław Mróz (5) 169757

(1) Radaszewski Tomasz (2) Teologia biskupstwa w świetle artykułów „, Ateneum kaptańskiego" (1909-2003) (3) ks. dr hab. Wojciech Hanc (4) ks. dr hab. Janusz Gręźlikowski (5) 163824 
(1) Rakowska Marzenna (2) Wychowanie do wolności w świetle orędzi Jana Pawta II do młodych (3) ks. dr hab. Zbigniew Wanat (4) ks. prof. dr hab. Mirosław Mróz (5) 169758

(1) Rusiniak Mirosława (2) Działalność charytatywna w archidiecezji gnieźnieńskiej od 1990 do 2003 roku (3) ks. dr Krzysztof Lewandowski (4) ks. prof. dr hab. Ireneusz Werbiński (5) 169759

(1) Rutkowska Ewa (2) Odkrywanie sensu cierpienia w świetle wypowiedzi Ojca Świętego Jana Pawta II (3) ks. dr hab. Zbigniew Wanat (4) ks. dr hab. Marian Graczyk (5) 169760

(1) Rutkowska Urszula (2) Teologiczno-pastoralne treści odnowionego obrzędu chrztu (3) ks. prof. dr hab. Jan Perszon (4) ks. prof. dr hab. Mirosław Mróz (5) 169761

(1) Sempołowicz Marlena (2) Powołanie do odpowiedzialnego rodzicielstwa. Studium teologicznomorlane (3) ks. dr hab. Zbigniew Wanat (4) ks. prof. dr hab. Mirosław Mróz (5) 169763

(1) Staszak Mariusz (2) Aktualizacja kerygmatu czytań biblijnych osiemnastej Niedzieli Zwyklej Roku C w kaznodziejstwie polskim w latach 1974-2001 (3) ks. dr hab. Tadeusz Lewandowski (4) ks. prof. dr hab. Krzysztof Konecki (5) 163825

(1) Strzelecka Renata (2) Prawa i obowiązki rodziców związane z chrztem dzieci w przepisach prawa kanonicznego (3) ks. dr hab. Janusz Gręźlikowski (4) ks. dr hab. Krzysztof Krzemiński (5) 169765

(1) Stysiek Helena (2) Religijne wychowanie dziecka przedszkolnego w świetle programu ,Jezus Chrystus z nami” pod red. ks. Władystawa Kubika (3) dr hab. Beata Bilicka (4) ks. prof. dr hab. Dariusz Kotecki (5) 169766

(1) Suwiński Jacek (2) Rady ewangeliczne w formacji podstawowej do kapłaństwa wedtug ,Dziennika duszy” bt. Jana XXIII (3) ks. dr hab. Stanisław Suwiński (4) ks. prof. dr hab. Ireneusz Werbiński (5) 163234

(1) Szczawińska Barbara (2) Natura matżeństwa i rodziny w świetle dokumentów pontyfikatu Jana Pawta II (3) ks. prof. dr hab. Jan Perszon (4) ks. dr hab. Zbigniew Wanat (5) 169767

(1) Sztuczka Mirosława (2) Udziat rodziny w rozwoju życia religijnego u dzieci w nauczaniu Jana Pawła II w latach 1981-1994 (3) ks. dr hab. Marian Graczyk (4) ks. dr hab. Zbigniew Wanat (5) 169768

(1) Ślusarz Adam (2) Zarys dziejów parafii Błędowo (3) ks. dr hab. Witold Kujawski (4) ks. dr hab. Wojciech Frątczak (5) 169769

(1) Świątkowska Jadwiga (2) Rola i zadania poradnictwa rodzinnego $w$ duszpasterstwie malżeństw i rodzin $w$ archidiecezji gnieźnieńskiej (3) ks. dr Krzysztof Lewandowski (4) ks. prof. dr hab. Ireneusz Werbiński (5) 169770

(1) Tarkowska Jolanta (2) Metody wyrażania doświadczeń inspirowanych tekstem biblijnym w katechezie II etapu edukacyjnego (3) dr hab. Beata Bilicka (4) ks. prof. dr hab. Dariusz Kotecki (5) 169771

(1) Tomaszewski Tomasz (2) Wychowanie młodzieży do malżeństwa w katechezie gimnazjalnej w świetle programu , $W$ drodze do Ojca” pod red. ks. T. Śmiecha (3) dr hab. Beata Bilicka (4) ks. prof. dr hab. Dariusz Kotecki (5) 169772 
(1) Trzebiatowski Tomasz (2) Działalność chórów kościelnych Torunia w latach 1920-1939 (3) ks. prof. dr hab. Anastazy Nadolny (4) ks. dr Mariusz Klimek (5) 163235

(1) Waks Andrzej (2) Cnota wiary a godność osoby ludzkiej w świetle traktatu „De fide” Św. Tomasza z Akwinu z ,Summa Theologiae” II-II, qq. 1-16 (3) ks. prof. dr hab. Mirosław Mróz (4) ks. dr hab. Marian Graczyk (5) 163236

(1) Wieluńska Katarzyna (2) Postuga katechety świeckiego w polskiej szkole po 1990 roku (3) dr hab. Beata Bilicka (4) ks. prof. dr hab. Dariusz Kotecki (5) 169774

(1) Wiśniewska Jolanta (2) Udział społeczeństwa w kształtowaniu postaw ludzkich na podstawie nauczania Jana Pawła II (1979-1994) (3) ks. dr hab. Marian Graczyk (4) ks. dr hab. Zbigniew Wanat (5) 169775

(1) Witkowicz Elżbieta (2) Kościót domowy miejscem sprawowania błogosławieństw w świetle księgi liturgicznej „,Obrzędy błogosławieństw dostosowane do zwyczajów diecezji polskich” (3) ks. dr Krzysztof Lewandowski (4) ks. prof. dr hab. Ireneusz Werbiński (5) 169776

(1) Witulla Krystyna (2) Wychowanie liturgiczne w katechezie klas I-III szkoły podstawowej w świetle programu ks. Tadeusza Śmiecha (3) dr hab. Beata Bilicka (4) ks. prof. dr hab. Dariusz Kotecki (5) 169777

(1) Wojnowska Anna (2) Rola świeckich w misji Kościoła na podstawie wybranych dokumentów Jana Pawła II (3) ks. dr hab. Marian Graczyk (4) ks. dr hab. Zbigniew Wanat, (5) 169778

(1) Wójcik Leszek (2) Błogosławiony Stefan Wincenty Frelichowski, jako patron Związu Harcerstwa Polskiego (3) ks. dr hab. Witold Kujawski (4) ks. dr hab. Wojciech Frątczak (5) 169779

(1) Zagacka Izabela (2) Zastosowanie Pisma Świętego w katechezie gimnazjalnej na podstawie podręczników metodycznych , W drodze do Emaus” (3) dr hab. Beata Bilicka (4) ks. prof. dr hab. Dariusz Kotecki (5) 169780

(1) Zalewska Dorota (2) Jedność i nierozerwalność malżeństwa $w$ dokumentach papieskich po Soborze Watykańskim II (3) ks. prof. dr hab. Jan Perszon (4) ks. dr hab. Zbigniew Wanat (5) 169781

(1) Zieliński Marcin (2) Podstawy życia duchowego chrześcijanina wedtug bt. Marii Karłowskiej (3) ks. dr hab. Stanisław Suwiński (4) ks. prof. dr hab. Ireneusz Werbiński (5) 163238

(1) Zieliński Rafał (2) Funkcja spowiednika w świetle Przemówień Jana Pawła II do Penitencjarii Apostolskiej w latach: 1981-2003 (3) ks. dr hab. Jacek Szymański (4) ks. dr hab. Janusz Grę́likowski (5) 163828

(1) Zuzga Ewa (2) Świętowanie niedzieli w świetle nauczania Jana Pawła II (3) ks. dr Krzysztof Lewandowski (4) ks. prof. dr hab. Ireneusz Werbiński (5) 169782

(1) Żebrowska Małgorzata (2) Dzieje parafii pw. św. Katarzyny Aleksandryjskiej $w$ Wielkiem Czystem (3) ks. dr hab. Witold Kujawski (4) ks. dr hab. Wojciech Frątczak (5) 169783 


\section{5}

(1) Adamczyk Sebastian (2) Realizacja programu duszpasterskiego „Poznać Chrystusa" na rok 2001/2002 w przekazie kaznodziejskim (3) ks. prof. dr hab. Krzysztof Konecki (4) ks. dr hab. Tadeusz Lewandowski (5) 163799

(1) Bednarczyk Jan (2) Odpowiedzialność za mitość $i$ wspólnotę życia $w$ matżenstwie $i$ rodzinie wedtug Jana Pawła II (3) ks. dr Bogusław Kwiatkowski (4) ks. prof. dr hab. Czesław Rychlicki (5) 186134

(1) Belzyt Barbara (2) Droga dobroczynności w duchowości wolontariatu (3) ks. dr hab. Stanisław Suwiński (4) ks. prof. dr hab. Ireneusz Werbiński (5) 186 135

(1) Borowski Paweł (2) Katecheza rodziców jako fundament chrześcijańskiej formacji dzieci i młodzieży $w$ świetle posoborowych dokumentów katechetycznych Kościoła katolickiego (3) dr hab. Beata Bilicka (4) ks. prof. dr hab. Jerzy Bagrowicz (5) 163214

(1) Buława Włodzimierz (2) Miejsce Eucharystii w ,nowej ewangelizacji” wedtug Jana Pawła II (3) ks. dr Bogusław Kwiatkowski (4) ks. prof. dr hab. Czesław Rychlicki (5) 186136

(1) Chachuła Katarzyna (2) Nauka o usprawiedliwieniu w katechizmie Kościoła Katolickiego (3) ks. dr Bogusław Kwiatkowski (4) ks. prof. dr hab. Czesław Rychlicki (5) 186137

(1) Chmielewski Jacek (2) Liturgia Godzin po Soborze Watykańskim II w świetle polskiej literatury teologicznej (3) ks. dr hab. Jacek Szymański (4) ks. prof. dr hab. Krzysztof Konecki (5) 163800

(1) Cybulska Jolanta (2) Ewangelizacyjna wartość Sakramentu Pokuty w programie duszpasterskim Episkopatu Polski przed Wielkim Jubileuszem Roku 2000 (3) ks. dr Bogusław Kwiatkowski (4) ks. prof. dr hab. Czesław Rychlicki (5) 186138

(1) Frankiewicz Patryk (2) Ambona jako miejsce proklamacji Słowa Bożego w Liturgii rzymskiej (3) ks. dr hab. Daniel Brzeziński (4) ks. prof. dr hab. Krzysztof Konecki (5) 163217

(1) Fydryszewski Mariusz (2) Zastosowanie komputera w szkolnej katechezie młodzieży (3) dr hab. Beata Bilicka (4) ks. prof. dr hab. Mirosław Mróz (5) 186140

(1) Garnuszek Cezary (2) Masturbacja jako akt wewnętrznie nieuporządkowany $w$ świetle deklaracji „Persona Humana” (3) ks. prof. dr hab. Krzysztof Konecki (4) ks. dr hab. Jacek Szymański (5) 163802

(1) Jabłońska Dorota (2) Rola i zadania katechety świeckiego w świetle Dyrektorium katechetycznego Kościoła katolickiego w Polsce (3) dr hab. Beata Bilicka (4) ks. prof. dr hab. Mirosław Mróz (5) 186142

(1) Jankowski Artur (2) Wspólnota życia i miłości podstawą rozwoju osoby i spoŁeczeństwa w świetle nauczania Jana Pawła II (3) ks. prof. dr hab. Jan Perszon (4) ks. prof. dr hab. Czesław Rychlicki (5) 163218

(1) Janus Wanda (2) Wptyw modlitwy na rozwój życia duchowego rodziny (3) ks. dr hab. Stanisław Suwiński (4) ks. prof. dr hab. Ireneusz Werbiński (5) 186 143 
(1) Jutel Elżbieta (2) Duchowość matżeńska w nauczaniu Jana Pawła II na podstawie wybranych źródet (3) ks. dr hab. Stanisław Suwiński (4) ks. prof. dr hab. Ireneusz Werbiński (5) 186144

(1) Kaźmierczak Kamilla (2) Maryja w misterium trójjedynego Boga w świetle nauczania Jana Pawła II (3) ks. dr Bogusław Kwiatkowski (4) ks. prof. dr hab. Czesław Rychlicki (5) 186145

(1) Kędzierska Wiesława (2) Duchowy obraz kobiety w nauczaniu Jana Pawła II (3) ks. dr hab. Stanisław Suwiński (4) ks. prof. dr hab. Ireneusz Werbiński (5) 186146

(1) Komorowski Jarosław (2) Drama w katechezie szkolnej (3) dr hab. Beata Bilicka (4) ks. prof. dr hab. Mirosław Mróz (5) 186147

(1) Konczalski Waldemar (2) Formacja duchowa kapłana na podstawie „Listów” Jana Pawła II na Wielki Czwartek (3) ks. dr hab. Stanisław Suwiński (4) ks. prof. dr hab. Ireneusz Werbiński (5) 163219

(1) Krajniewski Tadeusz (2) Życie duchowe chrześcijanina na podstawie kwartalnika ,Życie Duchowe” w latach (1994-2004) (3) ks. dr hab. Stanisław Suwiński (4) ks. prof. dr hab. Ireneusz Werbiński (5) 186148

(1) Kubacka-Cholewa Małgorzata (2) Tajemnica uświęcania świata poprzez cierpienie w nauczaniu Jana Pawła II (3) ks. dr Bogusław Kwiatkowski (4) ks. prof. dr hab. Czesław Rychlicki (5) 186149

(1) Kuna Damian (2) Wychowawcza rola sportu w ksztaltowaniu postaw moralnych człowieka $w$ świetle nauki św. Tomasza z Akwinu (3) ks. prof. dr hab. Mirosław Mróz (4) ks. prof. dr hab. Ireneusz Werbiński (5) 163220

(1) Leśniak Mirosława (2) Wyobraźnia miłosierdzia w życiu i myśli błogosławionej Matki Teresy (3) ks. dr hab. Stanisław Suwiński (4) ks. prof. dr hab. Ireneusz Werbiński (5) 186150

(1) Maciaszek Krzysztof (2) Sakrament namaszczenia chorych w świetle uchwat Drugiego Synodu Diecezji Włocławskiej z 1994 roku (3) ks. dr hab. Wojciech Hanc (4) ks. dr hab. Janusz Gręźlikowski (5) 163804

(1) Matusiak Mariusz (2) Obrazy nieba we wspótczesnych polskich podręcznikach dogmatycznych (3) ks. dr hab. Krzysztof Krzemiński (4) ks. prof. dr hab. Czesław Rychlicki (5) 163221

(1) Michalska Ewa (2) Przygotowanie młodzieży gimnazjalnej do sakramentu bierzmowania na przyktadzie programu pod red. ks. Tadeusza Śmiecha (3) dr hab. Beata Bilicka (4) ks. prof. dr hab. Mirosław Mróz (5) 186151

(1) Misiak Dawid (2) Jedność Kościoła w nauczaniu Jana Pawła II (3) ks. dr Bogusław Kwiatkowski (4) ks. prof. dr hab. Czesław Rychlicki (5) 186152

(1) Nawrocki Robert (2) Aktualizacja kerygmatu czytań biblijnych uroczystości W.N.M.P. w kaznodziejstwie polskim w latach 1975-2004 (3) ks. prof. dr hab. Krzysztof Konecki (4) ks. dr hab. Tadeusz Lewandowski (5) 163807

(1) Niścigorska Krystyna (2) Zasada pogladowości w zastosowaniu katechetycznym na poziomie szkoły podstawowej i gimnazjum (3) dr hab. Beata Bilicka (4) ks. prof. dr hab. Mirosław Mróz (5) 186154 
(1) Nowicki Marcin (2) Chrystocentryczny charakter kultu Maryi w polskiej posoborowej literaturze teologicznej (3) ks. prof. dr hab. Jan Perszon (4) ks. prof. dr hab. Czesław Rychlicki (5) 163222

(1) Orzechowska Bernarda (2) Pokusy w życiu duchownym chrześcijanina wedtug księdza Piotra Semenenki CR (3) ks. dr hab. Stanisław Suwiński (4) ks. prof. dr hab. Ireneusz Werbiński (5) 186155

(1) Piecyk Mariusz (2) Ekumeniczny wymiar pokuty i pojednania w świetle międzywyznaniowych dialogów doktrynalnych (3) ks. dr hab. Janusz Gręźlikowski (4) ks. dr hab. Wojciech Hanc (5) 163808

(1) Plechowska Anna (2) Kierownictwo duchowe w ,Listach” Ojca Pio (3) ks. dr hab. Stanisław Suwiński (4) ks. prof. dr hab. Ireneusz Werbiński (5) 186156

(1) Pyszna Arleta (2) Eklezjologiczny wymiar mariologii Jana Pawta II (3) ks. dr Bogusław Kwiatkowski (4) ks. prof. dr hab. Czesław Rychlicki (5) 187322

(1) Rakowska Danuta (2) Eucharystia jako droga uświęcenia wspólnoty Kościoła $w$ duszpasterskim programie Episkopatu Polski przed Wielkim Jubileuszem (3) ks. dr Bogusław Kwiatkowski (4) ks. prof. dr hab. Czesław Rychlicki (5) 186157

(1) Rembeza Małgorzata (2) Wychowanie dzieci i młodzieży do modlitwy w świetle nowego „,Programu nauczania religii” (3) dr hab. Beata Bilicka (4) ks. prof. dr hab. Mirosław Mróz (5) 186158

(1) Sadowski Michał (2) Kościót a globalizacja w świetle adhortacji „Ecclesia in America” (3) ks. prof. dr hab. Krzysztof Konecki (4) ks. dr hab. Jacek Szymański (5) 163809

(1) Sęczkowska Anna (2) Wychowawcze zadania rodziców i ich realizacja wobec wspótczesnych zagrożeń w świetle adhortacji „Familiaris consortio” Jana Pawła II (3) dr hab. Beata Bilicka (4) ks. prof. dr hab. Mirosław Mróz (5) 186 159

(1) Słowik Maria (2) Katecheza przedszkolna droga do doświadczenia Boga na przyktadzie programu „Radość dzieci Bożych” (3) dr hab. Beata Bilicka (4) ks. prof. dr hab. Mirosław Mróz (5) 186160

(1) Sobierajski Sławomir (2) Vita in Christo Iesu. Elementy chrystianologii moralnej w świetle „Super Epistolam s. Pauli Apostoli ad Romanos” św. Tomasza $z$ Akwinu (3) ks. prof. dr hab. Mirosław Mróz (4) ks. prof. dr hab. Waldemar Chrostowski (5) 163224

(1) Sprynger Andżelika (2) Obecność i działanie Ducha Świętego w Kościele na podstawie dokumentów Kościoła Powszechnego oraz Programów Duszpasterskich Komisji Duszpasterskiej Episkopatu Polski przed Wielkim Jubileuszem Roku 2000 (3) ks. dr Bogusław Kwiatkowski (4) ks. prof. dr hab. Czesław Rychlicki (5) 186161

(1) Stawicki Krzysztof (2) Problem kary śmierci w świetle „Katechizmu Kościoła Katolickiego” (3) ks. dr hab. Janusz Gręźlikowski (4) ks. dr hab. Jacek Szymański (5) 163811

(1) Szczepańska Hanna (2) Język w katechezie a komunikacja wiary (3) dr hab. Beata Bilicka (4) ks. prof. dr hab. Mirosław Mróz (5) 186162 
(1) Szporka Maria (2) Świętość wedtug błogosławionej Matki Teresy z Kalkuty (3) ks. dr hab. Stanisław Suwiński (4) ks. prof. dr hab. Ireneusz Werbiński (5) 186163

(1) Sztylc Żaneta (2) Teologiczno-moralne implikacje problemu cierpienia w myśli psychologicznej C. G. Junga, V. E. Frankla i A. Kępińskiego (3) ks. prof. dr hab. Mirosław Mróz (4) prof. dr hab. Ireneusz Werbiński (5) 186164

(1) Szulc-Półtorak Jolanta (2) Rodzice pierwszymi katechetami w przygotowaniu dzieci do uczestnictwa $w$ życiu Kościoła $w$ świetle „Listu do Rodzin” Jana Pawła II (3) dr hab. Beata Bilicka (4) ks. prof. dr hab. Mirosław Mróz (5) 186 165

(1) Szymaniak Dawid (2) Iustitia est ad altrum. Aktualność myśli św. Tomasza z Akwinu o cnocie sprawiedliwości w świetle ,Summa Theologiae” II - II qq. 57-122 (3) ks. prof. dr hab. Mirosław Mróz (4) ks. prof. dr hab. Ireneusz Werbiński (5) 163226

(1) Terlecka Barbara (2) Rodzina wobec wspótczesnych wyzwań kulturowych w nauczaniu posoborowym Kościoła (3) ks. dr Bogusław Kwiatkowski (4) ks. prof. dr hab. Czesław Rychlicki (5) 186166

(1) Teska Maryla (2) Zastosowanie obrazu w katechezie dzieci i młodzieży (3) dr hab. Beata Bilicka (4) ks. prof. dr hab. Mirosław Mróz (5) 186167

(1) Tretyn Joanna (2) Duchowy wymiar chrześcijańskiego cierpienia w świetle orędzia do chorych Jana Pawła II (3) ks. dr hab. Stanisław Suwiński (4) ks. prof. dr hab. Ireneusz Werbiński (5) 186168

(1) Tuszyńska Ilona (2) Metodyka pracy z Pismem Świętym na katechezie na przykładzie przewodników metodycznych pod redakcją ks. Tadeusza Śmiecha (3) dr hab. Beata Bilicka (4) ks. prof. dr hab. Mirosław Mróz (5) 186169

(1) Wałdowski Marcin (2) Zabór i rewindykacja kościoła św. Jakuba Apostoła w Toruniu (3) ks. prof. dr hab. Anastazy Nadolny (4) ks. dr hab. Witold Kujawski (5) 163237

(1) Wasilewski Dawid (2) Teologiczne treści egzorcyzmu w Rytuale Rzymskim. Studium teologicznodogmatyczne (3) ks. dr hab. Krzysztof Krzemiński (4) ks. prof. dr hab. Czesław Rychlicki (5) 163227

(1) Wesół Andrzej (2) Katecheza dorostych w świetle dokumentu „Katecheza dorostych we wspólnocie chrześcijańskiej" Międzynarodowej Rady do Spraw Katechezy (3) dr hab. Beata Bilicka (4) ks. prof. dr hab. Mirosław Mróz (5) 186170

(1) Wiśniewska Mirosława (2) Duchowość Komunii osób na przykładzie wspólnoty Domowego Kościoła (3) ks. dr hab. Stanisław Suwiński (4) ks. prof. dr hab. Ireneusz Werbiński (5) 186171

(1) Zydor Agnieszka (2) Chrystocentryczny wymiar zycia i postugi kaptana na podstawie ,Listów” Jana Pawła II do kapłanów na Wielki Czwartek (3) ks. dr Bogusław Kwiatkowski (4) ks. prof. dr hab. Czesław Rychlicki (5) 186172

$$
2006
$$

(1) Biernacka Aleksandra (2) Metody aktywizujace w katechezie gimnazjalnej (3) dr hab. Beata Bilicka (4) ks. prof. dr hab. Ireneusz Werbiński (5) 162112 
(1) Biernat Artur (2) Utrata zmysłu grzechu w życiu czlowieka w świetle adhortacji ,, Reconciliatio et paenitentia” (3) ks. dr hab. Jacek Szymański (4) ks. prof. dr hab. Krzysztof Konecki (5) 198773

(1) Bochen Rafał (2) Sytuacja kanoniczna matżenstw nieregularnych w świetle ustawodawstwa kościelnego (3) ks. dr hab. Wiesław Kraiński (4) ks. dr hab. Janusz Gręźlikowski (5) 175439

(1) Dąbrowska Monika (2) Powołanie do miłości w świetle wypowiedzi Jana Pawła II do młodych (3) ks. dr hab. Zbigniew Wanat (4) ks. dr hab. Zbigniew Wanat (5) 162097

(1) Dąbrowski Paweł (2) Parafia p.w. św. Małgorzaty w Łobdowie (3) ks. dr hab. Witold Kujawski (4) ks. prof. dr hab. Anastazy Nadolny (5) 163189

(1) Dynakowski Robert (2) Kaplan a Sakrament Pokuty i Pojednania w świetle „Listów” Jana Pawła II do kaptanów na Wielki Czwartek (3) ks. dr hab. Jacek Szymański (4) ks. prof. dr hab. Krzysztof Konecki (5) 163779

(1) Felczykowska Barbara (2) Etyczny aspekt leczenia niepłodności w świetle instrukcji Kongregacji Nauki Wiary „,Donum vitae” (3) ks. dr hab. Zbigniew Wanat (4) ks. prof. dr hab. Mirosław Mróz (5) 157454

(1) Galanciak Dawid (2) Kapłan jako katecheta i duszpasterz młodzieży w świetle dokumentów katechetyczno-pastoralnych po Soborze Watykańskim II (3) dr hab. Beata Bilicka (4) ks. prof. dr hab. Jerzy Bagrowicz (5) 163190

(1) Goliasz Kamil (2) Hermeneutyka nadziei w świetle wybranych pism Paula Ricoeura (3) ks. prof. dr hab. Mirosław Mróz (4) ks. prof. dr hab. Ireneusz Werbiński (5) 157458

(1) Grabowska Anna (2) Zastosowanie środków dydaktycznych w katechezie na poziomie szkoły podstawowej (3) dr hab. Beata Bilicka (4) ks. prof. dr hab. Ireneusz Werbiński (5) 162104

(1) Janczak Karolina (2) Parafia Najświętszej Maryi Panny Częstochowskiej Ojców Paulinów w Toruniu w latach 1996-2005 (3) ks. prof. dr hab. Anastazy Nadolny (4) ks. dr hab. Witold Kujawski (5) 157463

(1) Januszewski Marek (2) Duchowość młodzieży w świetle nauczania Jana Pawta II (3) ks. prof. dr hab. Ireneusz Werbiński (4) ks. dr hab. Stanisław Suwiński (4) ks. prof. dr hab. Mirosław Mróz (5) 163192

(1) Kamińska Monika (2) Troska o owocne przeżywanie sakramentalnego matżeństwa wedtug nauczania Jana Pawła II (3) ks. dr hab. Zbigniew Wanat (4) ks. prof. dr hab. Mirosław Mróz (5) 162105

(1) Kamiński Arkadiusz (2) Obowiąki malżeńskie w przepisach prawa kanonicznego i polskiego (3) ks. dr hab. Janusz Gręźlikowski (4) ks. dr hab. Wiesław Kraiński (5) 163780

(1) Kaszuba Dawid (2) Wptyw Radia Maryja na postawy duchowe stuchaczy (3) ks. prof. dr hab. Ireneusz Werbiński (4) ks. prof. dr hab. Mirosław Mróz (5) 162106

(1) Kleczewski Tomasz (2) Ochrona prawna dziecka poczętego w świetle przepisów prawa kanonicznego i prawa polskiego (3) ks. dr hab. Janusz Gręźlikowski (4) ks. prof. dr hab. Krzysztof Konecki (5) 163781 
(1) Kochalska Magdalena (2) Świętość na przykładzie Andrzeja Boboli (3) ks. prof. dr hab. Ireneusz Werbiński (4) ks. prof. dr hab. Mirosław Mróz (5) 157 472

(1) Kozyra Andrzej (2) Koncepcja szczęścia chrześcijańskiego w świetle „De sermone Domini in monte" św. Augustyna (3) ks. prof. dr hab. Mirosław Mróz (4) ks. prof. dr hab. Ireneusz Werbiński (5) 162108

(1) Kwiatkowska Anna (2) Żal za grzechy w świetle Katechizmu Kościoła Katolickiego (3) ks. prof. dr hab. Mirosław Mróz (4) ks. prof. dr hab. Ireneusz Werbiński (5) 157486

(1) Lipiński Dariusz (2) Wpływ narkomanii na ważność matżeństwa w świetle przepisów prawa kanonicznego (3) ks. dr hab. Janusz Gręźlikowski (4) ks. prof. dr hab. Krzysztof Konecki (5) 187259

(1) Lis Adam (2) Dzieje Zgromadzenia Sióstr Miłosierdzia w Chetmnie od osiedlenia do wybuchu II wojny światowej 1694-1939 (3) ks. dr hab. Witold Kujawski (4) ks. prof. dr hab. Anastazy Nadolny (5) 163193

(1) Lis Joanna (2) Duchowa postuga Kościoła osobom chorym psychicznie zobrazowana doświadczeniem duszpasterskim w Wojewódzkim Szpitalu dla Nerwowo i Psychicznie Chorych im. dr. Józefa Bednarza w Świeciu nad Wista (3) ks. prof. dr hab. Ireneusz Werbiński (4) ks. prof. dr hab. Mirosław Mróz (5) 162991

(1) Maciejko Jakub (2) Troska Episkopatu Polski o reformę Liturgii Eucharystycznej po Soborze Watykańskim II (1965-2005) (3) ks. dr hab. Daniel Brzeziński (4) ks. prof. dr hab. Krzysztof Konecki (5) 163194

(1) Malinowski Tomasz (2) Przeszkody do zawarcia matżeństwa $w$ obowiazujacym prawie kanonicznym i prawie polskim (3) ks. dr hab. Janusz Gręźlikowski (4) ks. dr Roman Małecki (5) 163786

(1) Marks Dorota (2) Kremacja zwłok w obowiazującym prawie kanonicznym $i$ polskim (3) ks. dr hab. Janusz Gręźlikowski (4) ks. prof. dr hab. Krzysztof Konecki (5) 162115

(1) Matynka Marcin (2) Matżeństwo i rodzina w świetle uchwat II synodu diecezji włocławskiej z 1994 roku (3) ks. dr hab. Janusz Gręźlikowski (4) ks. prof. dr hab. Krzysztof Konecki (5) 163787

(1) Michalczuk Karol (2) Rola i zadania Kapituly Prowincjalnej na przykladzie Prowincji Warszawskiej Redemptorystów (3) ks. dr hab. Janusz Gręźlikowski (4) ks. dr hab. Wiesław Kraiński (5) 199385

(1) Nastarowicz Radosław (2) Aktualizacja kerygmatu czytań biblijnych trzydziestej Niedzieli Zwyktej Roku C w kaznodziejstwie polskim w latach 1974-2004 (3) ks. dr hab. Tadeusz Lewandowski (4) ks. prof. dr hab. Krzysztof Konecki (5) 163806

(1) Nowak Łukasz (2) Wolność sumienia $i$ wyznania w świetle Konstytucji Rzeczypospolitej Polskiej z dnia 2 kwietnia 1997 roku (3) ks. dr hab. Janusz Gręźlikowski (4) ks. prof. dr hab. Krzysztof Konecki (5) 198772

(1) Nowak Sławomira (2) Chrystologia New Age-odpowiedź chrześcijaństwa w świetle dokumentu Jezus Chrystus Dawca Wody Żywej (3) ks. prof. dr hab. Jan Perszon (4) ks. dr hab. Tomasz Dutkiewicz (5) 162990 
(1) Oparka Aleksandra (2) Rola cnoty roztropności w dążeniu czlowieka do celu ostatecznego w świetle ,Summa Theologiae” św. Tomasza z Akwinu (3) ks. prof. dr hab. Mirosław Mróz (4) ks. prof. dr hab. Ireneusz Werbiński (5) 157 496

(1) Osicki Wojciech (2) Kongres eucharystyczny w Toruniu (27-30 maja 1929r.). Geneza, celebracja, przestanie teologiczno-pastoralne (3) ks. prof. dr hab. Krzysztof Konecki (4) ks. dr hab. Daniel Brzeziński (5) 163195

(1) Pelc Tomasz (2) Katecheza młodzieży ponadgimnazjalnej w świetle dokumentów katechetycznych Kościoła katolickiego w Polsce (3) dr hab. Beata Bilicka (4) ks. prof. dr hab. Ireneusz Werbiński (5) 198781

(1) Płóciennik Łukasz (2) Prawo pogrzebowe w aktualnych normach prawa kanonicznego i przepisach prawa polskiego (3) ks. dr hab. Janusz Gręźlikowski (4) ks. prof. dr hab. Krzysztof Konecki (5) 163789

(1) Przybyszewski Paweł (2) Teologia Miłosierdzia Bożego w ujęciu , szkoły pallotyńskiej” (3) ks. dr hab. Krzysztof Krzemiński (4) ks. prof. dr hab. Jan Perszon (5) 157502

(1) Radzimińska Paulina (2) Modlitwa chrześcijańska na przykładzie publikacji pt. „Bezimienni mówiq o modlitwie” (3) ks. prof. dr hab. Ireneusz Werbiński (4) ks. prof. dr hab. Mirosław Mróz (5) 157505

(1) Różycka Agnieszka (2) Inkulturacja $w$ Afryce w oparciu o nauczanie Jana Pawła II i Synodu Afrykańskiego (3) ks. prof. dr hab. Jan Perszon (4) ks. dr hab. Tomasz Dutkiewicz (5) 162133

(1) Ruszkowski Łukasz (2) Dialog Kościoła z islamem w nauczaniu Jana Pawła II (3) ks. prof. dr hab. Jan Perszon (4) ks. dr hab. Tomasz Dutkiewicz (5) 157 506

(1) Skierkiewicz Marcin (2) Boże Miłosierdzie w życiu chrześcijanina (w ujęciu ks. M. Sopoćko) (3) ks. prof. dr hab. Jan Perszon (4) ks. dr hab. Krzysztof Krzemiński (5) 163198

(1) Skowroński Michał (2) Wpływ chorób psychicznych na zdolność do zawarcia matżeństwa w świetle prawa kanonicznego (3) ks. dr hab. Janusz Gręźlikowski (4) ks. prof. dr hab. Krzysztof Konecki (5) 163791

(1) Snopek Łukasz (2) On zaś chrzcić Was będzie Duchem Świętym (Mk 1, 8). Studium egzegetyczne (3) ks. bp prof. dr hab. Zbigniew Kiernikowski (4) ks. prof. dr hab. Dariusz Kotecki (5) 163199

(1) Szefler Elżbieta (2) Teologia męczeństwa w świetle nauczania Jana Pawła II (3) ks. prof. dr hab. Mirosław Mróz (4) ks. prof. dr hab. Ireneusz Werbiński (5) 157511

(1) Śmigielska Agnieszka (2) Kanoniczne przygotowanie do zawarcia malżeństwa w świetle przepisów prawa kanonicznego (3) ks. dr hab. Janusz Gręźlikowski (4) ks. prof. dr hab. Krzysztof Konecki (5) 162114

(1) Topolski Marcin (2) Choroba i cierpienie w świetle Orędzi Jana Pawła II na Światowy Dzień Chorego (3) ks. dr hab. Jacek Szymański (4) ks. dr hab. Janusz Gręźlikowski (5) 163793 
(1) Tykarski Sławomir (2) Strzeżcie się kwasu faryzeuszów i kwasu Heroda (Mk 8, 15). Studium egzegetyczne (3) ks. prof. dr hab. Dariusz Kotecki (4) ks. bp prof. dr hab. Zbigniew Kiernikowski (5) 163204

(1) Warachewicz Artur (2) Parafia p.w. św. Maksymiliana Marii Kolbe w latach 1980-2005 w Toruniu (3) ks. prof. dr hab. Anastazy Nadolny (4) ks. dr hab. Witold Kujawski (5) 163206

(1) Wasielewski Marcin (2) Eutanazja w świetle prawa kanonicznego, polskiego oraz europejskiego i światowego (3) ks. dr hab. Janusz Gręźlikowski (4) ks. prof. dr hab. Krzysztof Konecki (5) 163795

(1) Wiśniewski Marek (2) Udział Polaków w XXIII Międzynarodowym Kongresie Eucharystycznym w Wiedniu w 1912 roku (3) ks. prof. dr hab. Anastazy Nadolny (4) ks. dr hab. Witold Kujawski (5) 163209

(1) Wróblewski Jacek (2) Dzieje parafii p.w. św. Wawrzyńca w Ryńsku (3) ks. prof. dr hab. Jan Perszon (4) ks. prof. dr hab. Anastazy Nadolny (4) ks. dr hab. Witold Kujawski (5) 163211

(1) Zając Karol (2) Teologia i celebracja liturgii sakramentu pokuty i pojednania w nowym ,Ordo Paenitentiae” (3) ks. prof. dr hab. Krzysztof Konecki (4) ks. dr hab. Jacek Szymański (5) 163798

(1) Zamorowska Agnieszka (2) Miłosierdzie Boże w życiu i nauczaniu bt. Franciszki Siedliskiej (3) ks. prof. dr hab. Ireneusz Werbiński (4) ks. prof. dr hab. Mirosław Mróz (5) 157528

(1) Zięcina Honorata (2) Matżeństwo $i$ rodzina $w$ nauczaniu $i$ ustawodawstwie Jana Pawta II (3) ks. dr hab. Janusz Gręźlikowski (4) ks. prof. dr hab. Krzysztof Konecki (5) 157529

(1) Żuchowski Marek (2) Misja Jezusa w Mk 1, 35-39. Studium egzegetyczne (3) ks. bp prof. dr hab. Zbigniew Kiernikowski (4) ks. prof. dr hab. Dariusz Kotecki (5) 163212

\section{7}

(1) Adamczewski Mariusz (2) Zwiazki niesakramentalne w nauczaniu i obowiqzujacym ustawodawstwie Kościoła (3) ks. dr hab. Janusz Gręźlikowski (4) ks. dr hab. Wiesław Kraiński (5) 162092

(1) Biskup Izabela (2) Państwo pomocnicze wobec rodziny $w$ świetle „Listu do rodzin” Jana Pawła II (3) ks. dr hab. Wiesław Łużyński (4) ks. prof. dr hab. Mirosław Mróz (5) 172374

(1) Buta Jacek (2) Ciesz się młodzieńcze w młodości swojej - studium egzegetyczne Koh 11, 9-12,1 (3) ks. dr Stanisław Jankowski (4) ks. prof. dr hab. Waldemar Chrostowski (5) 162095

(1) Chamela Barbara (3) Znaczenie pustyni u Iz 40, 3 (3) ks. dr Tomasz Tułodziecki (4) ks. prof. dr hab. Dariusz Kotecki (5) 172383

(1) Chilińska Aleksandra (2) Kto straci swoje życie z powodu Mnie i Ewnagelii, ten je zachowa (Mk 8, 35 b). Studium egzegetyczno-teologiczne (3) ks. prof. dr hab. Dariusz Kotecki (4) ks. dr Tomasz Tułodziecki (5) 172388

(1) Chrząszcz Anna (2) Przykazanie miłości Boga i bliźniego we wspótczesnym nauczaniu religii na przykladzie wybranych serii podręczników katechetycz- 
nych (klasy I-VI) (3) ks. prof. dr hab. Jerzy Bagrowicz (4) dr hab. Beata Bilicka (5) 172390

(1) Cieślick Adam (2) Więź matżeńska w nauczaniu Jana Pawta II (3) ks. prof. dr hab. Jan Perszon (4) ks. dr Roman Małecki (5) 209506

(1) Dokurno Katarzyna (2) Scena uzdrowienia niewidomego z Betsaidy (Mk 8, 22-26). Studium egzegetyczne (3) ks. prof. dr hab. Dariusz Kotecki (4) ks. dr Tomasz Tułodziecki (5) 172398

(1) Drążela Katarzyna (2) Poszukiwanie projektu życia w młodości na podstawie Listu do młodych Jana Pawta II „Parati semper” (3) ks. prof. dr hab. Jerzy Bagrowicz (4) dr hab. Beata Bilicka (5) 172401

(1) Drozdecka Dorota (2) Nawrócenie i pojednanie droga powrotu do Boga w świetle adhortacji Jana Pawta II „Reconciliatio et paenitentia” (3) ks. prof. dr hab. Mirosław Mróz (4) ks. prof. dr hab. Ireneusz Werbiński (5) 172402

(1) Dymkowski Łukasz (2) Separacja matżeństwa. Historia instytucji oraz obowiazujące przepisy prawa kanonicznego, polskiego i europejskiego (3) ks. dr hab. Janusz Gręźlikowski (4) ks. dr hab. Wiesław Kraiński (5) 172404

(1) Felczykowski Paweł (2) Święty Augustyn „De disciplina christiana”: Wstęp, komentarz, ttumaczenie (3) ks. dr hab. Tomasz Kaczmarek (4) o. dr hab. Mieczysław Paczkowski (5) 192932

(1) Foligowski Krzysztof (2) Problem zbawienia dzieci zmartych bez chrztu we wspótczesnych dokumentach magistralnych Kościoła (3) ks. prof. dr hab. Czesław Rychlicki (4) ks. dr hab. Krzysztof Krzemiński (5) 157455

(1) Gill Monika (2) Nowy feminizm proponowany przez Jana Pawła II w oparciu o wybrane dokumenty i literature polska (3) ks. prof. dr hab. Jan Perszon (4) ks. dr Roman Małecki (5) 172410

(1) Grabowski Cezary (2) Koncepcje szlachetności: u Arystotelesa, św. Tomasza $z$ Akwinu i N. Hartmanna (3) prof. dr hab. Marian Grabowski (4) ks. prof. dr hab. Mirosław Mróz (5) 157460

(1) Helsztajn Kinga (2) Zagadnienie szczęścia w „Summa Theologica” św. Tomasza z Akwinu I-II, q. 1-5 (3) ks. prof. dr hab. Mirosław Mróz (4) ks. prof. dr hab. Ireneusz Werbiński (5) 172416

(1) Jabłońska Joanna (2) Przygotowanie młodzieży do sakramentu bierzmowania na podstawie podręczników pod redakcja ks. Jana Szpeta i Danuty Jackowiak (3) dr hab. Beata Bilicka (4) ks. prof. dr hab. Jerzy Bagrowicz (5) 172417

(1) Janiak Przemysław (2) Aktualizacja kerygmatu czytań biblijnych Piątej Niedzieli Wielkiego Postu Roku A w kaznodziejstwie polskim w latach 1974-2005 (3) ks. dr hab. Tadeusz Lewandowski (4) ks. prof. dr hab. Krzysztof Konecki (5) 162103

(1) Jankowiak Witold (2) Nawrócenie Szawła z Tarsu w świetle Kierkegaardiańskich kategorii prawdy i wolności (3) prof. dr hab. Marian Grabowski (4) ks. prof. dr hab. Dariusz Kotecki (5) 157464

(1) Kabała Ewelina (2) Dialog z islamem w polskiej literaturze teologicznej (3) ks. prof. dr hab. Jan Perszon (4) ks. dr Roman Małecki (5) 176247 
(1) Kaczmarek Robert (2) Zobowiazania moralne płynace z Eucharystii w świetle encykliki „Ecclesia de Eucharistia” (3) ks. dr hab. Jacek Szymański (4) ks. prof. dr hab. Krzysztof Konecki (5) 157467

(1) Kasprzyk Katarzyna (2) Wierzenia i obrzędy weselne w powiecie inowroctawskim na Kujawach (3) ks. prof. dr hab. Jan Perszon (4) ks. dr Roman Małecki (5) 172376

(1) Kiełpiński Krzysztof (2) Struktura organizacyjno-prawna diecezji toruńskiej w latach 1992-2005 (3) ks. dr hab. Janusz Gręźlikowski (4) ks. dr hab. Wiesław Kraiński (5) 157469

(1) Koczot Grzegorz (2) Kult blogostawionego Stefana Wincentego Frelichowskiego (1945-2005). Studium historyczno-liturgiczne (3) ks. dr hab. Daniel Brzeziński (4) ks. prof. dr hab. Krzysztof Konecki (5) 157474

(1) Koralewski Paweł (2) Rozwód jako zagrożenie wspótczesnego matżeństwa w świetle adhortacji ,Familiaris Consortio” (3) ks. dr hab. Jacek Szymański (4) ks. dr hab. Janusz Gręźlikowski (5) 157475

(1) Kucharska Arletta (2) Oczekiwanie Mesjasza w judaizmie na podstawie opracowań Rachmiela Frydlanda (3) ks. prof. dr hab. Jan Perszon (4) ks. dr Roman Małecki (5) 176246

(1) Lewandowska Karolina (2) Geniusz kobiety w świetle listu apostolskiego „, Mulieris dignitatem” Jana Pawta II (3) ks. dr hab. Krzysztof Krzemiński (4) ks. prof. dr hab. Jan Perszon (5) 172440

(1) Lewandowska Liliana (2) Ap 12 jako synteza demonologii biblijnej (3) ks. prof. dr hab. Dariusz Kotecki (4) ks. dr Tomasz Tułodziecki (5) 172412

(1) Lewandowski Adam (2) Wady zgody matżeńskiej jako przyczyna nieważnego zawarcia matżeństwa kanonicznego (3) ks. dr hab. Janusz Gręźlikowski (4) ks. dr hab. Wiesław Kraiński (5) 162111

(1) Lipińska Angelika (2) Diakonat stały w świetle przepisów prawa kanonicznego i dokumentów Kościoła Katolickiego (3) ks. dr hab. Janusz Gręźlikowski (4) ks. dr hab. Wiesław Kraiński (5) 172436

(1) Lutkiewicz Joanna (2) Starość jako dar i zadanie. Studium teologicznomoralne (3) ks. dr hab. Zbigniew Wanat (4) ks. prof. dr hab. Mirosław Mróz (5) 172 442

(1) Łazik Karol(2) Stwórz, o Boże, we mnie serce czyste i odnów w mojej piersi ducha niezwyciężonego! Nowe stworzenie owocem nawrócenia w świetle Psalmu 51 (3) ks. dr Stanisław Jankowski (4) ks. prof. dr hab. Waldemar Chrostowski (5) 162113

(1) Łukasik Barbara (2) Ideat rycerza chrześcijańskiego w świetle wypraw krzyżowych i regut zakonów rycerskich (3) ks. dr hab. Witold Kujawski (4) ks. prof. dr hab. Anastazy Nadolny (5) 172443

(1) Manikowski Artur (2) Kapłan Stuga Eucharystii w świetle wielkoczwartkowych listów Jana Pawła II do kaptanów (3) ks. dr hab. Daniel Brzeziński (4) ks. prof. dr hab. Jan Perszon (5) 209775

(1) Marcinkowski Przemysław (2) Wartości seksualne w ujęciach miłości Maxa Schelera i Karola Wojtyly (3) prof. dr hab. Marian Grabowski (4) ks. dr hab. Zbigniew Wanat (5) 172448 
(1) Marcinkowski Sławomir (2) Powołanie i Boże Macierzyństwo w pieśniach o NMP $w$ Kancjonatach diecezji (3) ks. prof. dr hab. Jan Perszon (4) ks. prof. dr hab. Czesław Rychlicki (5) 157489

(1) Marony Michał (2) Współodkupieńczy wymiar cierpienia ludzkiego w świetle „Listów” o. Pio (3) ks. dr hab. Krzysztof Krzemiński (4) ks. prof. dr hab. Czesław Rychlicki (5) 157490

(1) Matlak Anita (2) Biblijne podstawy obrazu Chrystusa Stugi w wybranych pismach Stugi Bożego ks. Franciszka Blachnickiego (3) ks. bp prof. dr hab. Zbigniew Kiernikowski (4) ks. prof. dr hab. Dariusz Kotecki (5) 172449

(1) Narodzonek Michał (2) Nauka o czyśćcu we wspótczesnej polskiej literaturze teologicznej (3) ks. prof. dr hab. Czesław Rychlicki (4) ks. dr hab. Krzysztof Krzemiński (5) 157493

(1) Nawrocka Wioleta (2) Ustrój i organizacja Diecezji Toruńskiej w latach 19922006. Studium historyczne (3) ks. prof. dr hab. Anastazy Nadolny (4) ks. dr hab. Witold Kujawski (5) 172460

(1) Opiela Edyta (2) Rozwój życia duchowego na przykładzie świętej Teresy od Dzieciatka Jezus i Najświętszego Oblicza (3) ks. prof. dr hab. Ireneusz Werbiński (4) ks. dr hab. Stanisław Suwiński (5) 162125

(1) Ossowski Szymon (2) Kultura jako czynnik narodotwórczy w nauczaniu Jana Pawła II do Polaków (3) ks. dr hab. Wiesław Łużyński (4) ks. prof. dr hab. Mirosław Mróz (5) 172466

(1) Paczewski Przemysław (2) Centralizacja kultu a problem w Deuteronomicznym dziele historycznym. Studium egzegetyczno-teologiczne (3) ks. dr Tomasz Tułodziecki (4) ks. prof. dr hab. Dariusz Kotecki (5) 172467

(1) Pelowski Wojciech (2) Dzieje parafii pod wezwaniem Podwyższenia Krzyża Świętego w Leśnie (3) ks. prof. dr hab. Anastazy Nadolny (4) ks. dr hab. Witold Kujawski (5) 163196

(1) Pesta Adam (2) Duchowość pracy ludzkiej w nauczaniu Stugi Bożego ks. kardynała Stefana Wyszyńskiego (3) ks. prof. dr hab. Ireneusz Werbiński (4) ks. dr hab. Stanisław Suwiński (5) 217533

(1) Piotrowska Anna (2) Dialog międzyreligijny i ekumeniczny w katechezie na przykładzie podręczników dla gimnazjum i szkót ponadgimnazjalnych (3) dr hab. Beata Bilicka (4) ks. prof. dr hab. Jerzy Bagrowicz (5) 162127

(1) Radtke Justyna (2) Chrześcijańska wizja wolności w twórczości Mikołaja Bierdiajewa (3) ks. prof. dr hab. Mirosław Mróz (4) ks. prof. dr hab. Ireneusz Werbiński (5) 172478

(1) Rolirad Krzysztof (2) Parafia Najświętszego Serca Pana Jezusa w Gniewkowie w latach 1969-2006 (3) ks. prof. dr hab. Anastazy Nadolny (4) ks. dr hab. Witold Kujawski (5) 162132

(1) Rumińska Danuta (2) Rodzice jako pierwsi katecheci w świetle zaleceń II Polskiego Synodu Plenarnego (1990-1999) i Dyrektorium katechetycznego Kościoła katolickiego w Polsce (3) dr hab. Beata Bilicka (4) ks. prof. dr hab. Jerzy Bagrowicz (5) 172488 
(1) Rybak Małgorzata (2) Tracenie $i$ wydawanie siebie $w$ Eucharystii w świetle $\mathrm{Hbr} 10$, 4-10 (3) ks. bp prof. dr hab. Zbigniew Kiernikowski (4) ks. prof. dr hab. Dariusz Kotecki (5) 172489

(1) Rydel Dorota (2) Pobożność maryjna w parafii pod wezwaniem Najświętszej Maryi Panny Częstochowskiej w Toruniu (3) ks. prof. dr hab. Jan Perszon (4) ks. dr Roman Małecki (5) 172419

(1) Sikora Bianka (2) Miasta ucieczki w Księdze Jozuego. Studium egzegetyczno-teologiczne Joz 20, 1-9 (3) ks. dr Tomasz Tułodziecki (4) ks. prof. dr hab. Dariusz Kotecki (5) 172491

(1) Starobrat Adriana (2) Dzieje parafii p.w. Narodzenia Najświętszej Maryi Panny w Czarżu (3) ks. prof. dr hab. Anastazy Nadolny (4) ks. dr hab. Witold Kujawski (5) 172502

(1) Stec Hanna (2) Obraz jako środek dydaktyczny w katechezie gimnazjalnej (3) dr hab. Beata Bilicka (4) ks. prof. dr hab. Jerzy Bagrowicz (5) 172503

(1) Stefańska Magdalena (2) Kryzys misji prorockiej Eliasza. Studium egzegetyczno-teologiczne $1 \mathrm{Krl} \mathrm{19,} \mathrm{1-18} \mathrm{(3)} \mathrm{ks.} \mathrm{dr} \mathrm{Tomasz} \mathrm{Tułodziecki} \mathrm{(4)} \mathrm{ks.} \mathrm{prof.} \mathrm{dr}$ hab. Dariusz Kotecki (5) 172504

(1) Stefański Marcin (2) Koncepcja człowieka w New Age (3) ks. prof. dr hab. Jan Perszon (4) ks. prof. dr hab. Mirosław Mróz (5) 163200

(1) Sternicki Szymon (2) Perykopa o chodzeniu Jezusa po morzu (Mk 6, 45-52). Studium egzegetyczne (3) ks. prof. dr hab. Dariusz Kotecki (4) ks. dr Tomasz Tułodziecki (5) 163201

(1) Szatkowska Alina (2) Ślub Nazireatu $w$ świetle Lb 6, 1-21 i jego recepcja w Biblii Hebrajskiej. Studium egzegetyczno-teologiczne (3) ks. dr Tomasz Tułodziecki (4) ks. prof. dr hab. Dariusz Kotecki (5) 172506

(1) Szubski Damian (2) Troska duszpasterska Kościoła o udział dzieci w Liturgii eucharystycznej po Soborze Watykańskim II (3) ks. dr Krzysztof Lewandowski (4) ks. prof. dr Mirosław Mróz (5) 218416

(1) Ściślewski Łukasz (2) Świętowanie niedzieli w nauczaniu i ustawodawstwie Kościoła (3) ks. dr hab. Janusz Gręźlikowski (4) ks. dr hab. Wiesław Kraiński (5) 157514

(1) Świątek Łukasz (2) Problem konsumizmu w świetle encykliki „Centesimus annus” (3) ks. dr hab. Jacek Szymański (4) ks. prof. dr hab. Krzysztof Konecki (5) 157515

(1) Teodorczyk Bogdan (2) Postugi i funkcje w posoborowej liturgii Kościoła w świetle literatury przedmiotu (3) ks. prof. dr hab. Krzysztof Konecki (4) ks. dr hab. Jacek Szymański (5) 157516

(1) Tomczak Sebastian (2) Symbol Apostolski w życiu starożytnego Kościoła (3) ks. dr hab. Tomasz Kaczmarek (4) ks. dr hab. Janusz Gręźlikowski (5) 157 518

(1) Tuszyńska Karolina (2) Osoby zwodzicieli w Apokalipsie św. Jana. Studium egzegetyczne czasownika (3) ks. prof. dr hab. Dariusz Kotecki (4) ks. dr Tomasz Tułodziecki (5) 172522 
(1) Wacławski Damian (2) Znaczenie Góry w scenie powołania Dwunastu Mk 3, 13-19. Studium egzegetyczno-teologiczne (3) ks. prof. dr hab. Dariusz Kotecki (4) ks. dr Tomasz Tułodziecki (5) 163205

(1) Wątorowski Mariusz (2) Maryjny wymiar duchowości w życiu i myśli św. Maksymiliana Marii Kolbego (3) ks. prof. dr hab. Ireneusz Werbiński (4) ks. dr hab. Stanisław Suwiński (5) 216069

(1) Welke Dariusz (2) Soteryjny charakter postugi anioła Rafała w Księdze Tobiasza (3) ks. dr Stanisław Jankowski (4) ks. prof. dr hab. Dariusz Kotecki (5) 172528

(1) Widźgowska Karolina (2) Pobożność ludowa w okresie Adwentu i Bożego Narodzenia w Kurzętniku (3) ks. prof. dr hab. Jan Perszon (4) ks. dr Roman Małecki (5) 172530

(1) Wojciechowski Daniel (2) Rola czystości w życiu duchowym młodzieży na podstawie artykułów zamieszczonych w czasopiśmie „Mitujcie się” (19962006) (3) ks. prof. dr hab. Ireneusz Werbiński (4) ks. dr hab. Stanisław Suwiński (5) 163827

(1) Wojciechowski Janusz (2) Kształt relacji prawnych między państwem a Kościołem w XX-leciu międzywojennym (3) ks. dr hab. Janusz Gręźlikowski (4) ks. dr hab. Wiesław Kraiński (5) 172533

(1) Wojciechowski Leszek (2) Aktualizacja kerygmatu czytań biblijnych trzeciej Niedzieli Wielkiego Postu Roku A w kaznodziejstwie polskim w latach 19742005 (3) ks. dr hab. Tadeusz Lewandowski (4) ks. prof. dr hab. Krzysztof Konecki (5) 162143

(1) Wojnowski Mariusz (2) Kult łaskami stynacego wizerunku Matki Bożej Łaskawej w Grudziądzu (3) ks. dr hab. Daniel Brzeziński (4) ks. prof. dr hab. Krzysztof Konecki (5) 157525

(1) Wrońska Danuta (2) Komunikacja interpersonalna w katechetycznym przekazie wiary uczniów klasy III gimnazjum oraz klasy I szkoły ponadgimnazjalnej. Na podstawie literatury $i$ badań własnych (3) ks. prof. dr hab. Jerzy Bagrowicz (4) dr hab. Beata Bilicka (5) 172535

(1) Wypijacz Magdalena (2) Caritas jako miłość nadprzyrodzona w świetle „Quaestio disputata de caritate" św. Tomasza z Akwinu (3) ks. prof. dr hab. Mirosław Mróz (4) ks. prof. dr hab. Ireneusz Werbiński (5) 172536

(1) Wysocki Sławomir (2) Struktura diecezji włocławskiej po reorganizacji w roku 2004 (3) ks. dr hab. Janusz Gręźlikowski (4) ks. dr hab. Wiesław Kraiński (5) 157526

(1) Zbierzchowski Piotr (2) Egzystencjalny wymiar przemówień Jana Pawła II do młodzieży podczas pielgrzymek do ojczyzny (3) ks. dr hab. Tadeusz Lewandowski (4) ks. prof. dr hab. Jerzy Bagrowicz (5) 218157

(1) Żelazna Magdalena (2) Znaczenie krwi w rytach ofiarniczych Dnia Pojednania (Kpt 16, 1-34) (3) ks. dr Tomasz Tułodziecki (4) ks. prof. dr hab. Dariusz Kotecki (5) 172544 
2008

(1) Badaczewski Przemysław (2) Eklezjotwórczy charakter Eucharystii w świetle encykliki Jana Pawła II ,Ecclesia de Eucharistia” (3) ks. dr hab. Krzysztof Krzemiński (4) ks. prof. dr hab. Jan Perszon (5) 172368

(1) Banach Agnieszka (2) Ekskluzywizm soteriologiczny $w$ świetle teologii deklaracji „Dominus Iesus” (3) ks. dr Roman Małecki (4) ks. prof. dr hab. Jan Perszon (5) 186204

(1) Barański Grzegorz (2) Aktualizacja kerygmatu czytań biblijnych Mszy Wieczerzy Pańskiej w polskim kaznodziejstwie w latach 1974-2006 (3) ks. prof. dr hab. Jerzy Bagrowicz (4) ks. prof. dr hab. Krzysztof Konecki (5) 172370

(1) Bartczak Janusz (2) Symbolika wody w odnowionej Liturgii Wigilii Paschalnej (3) ks. prof. dr hab. Krzysztof Konecki (4) ks. dr hab. Daniel Brzeziński (5) 172371

(1) Borowska Aneta (2) Apokaliptyczna wizja Bestii w Dn 7, 1-8. Studium egzegetyczno-teologiczne (3) ks. dr Marek Raszewski (4) ks. prof. dr hab. Dariusz Kotecki (5) 186213

(1) Borucki Damian (2) Działalność kościelno-pasterska Biskupa Henryka Muszyńskiego w diecezji włocławskiej (1987-1992) (3) ks. dr hab. Janusz Gręźlikowski (4) ks. dr hab. Wiesław Kraiński (5) 172375

(1) Brzozowska Joanna (2) Eucharystyczny wymiar chrześcijańskiej rodziny w nauczaniu Jana Pawła II (3) ks. dr hab. Krzysztof Krzemiński (4) ks. prof. dr hab. Jan Perszon (5) 198770

(1) Budzyński Paweł (2) Dialog jako metoda ewangelizacji młodzieży. Formy $i$ sposoby jego realizacji na przykładzie Światowych Dni Młodzieży (3) ks. prof. dr hab. Jerzy Bagrowicz (4) ks. dr hab. Zbigniew Zarembski (5) 186216

(1) Czerniawska Renata (2) Poszukiwanie umiłowanego duszy w świetle Pnp 3, 1-4. Studium egzegetyczno-teologiczne (3) ks. dr Tomasz Tułodziecki (4) ks. prof. dr hab. Dariusz Kotecki (5) 186218

(1) Czerwiński Adam (2) Kult łaskami stynacego Obrazu Matki Bożej Brzemiennej (3) ks. dr hab. Daniel Brzeziński (4) ks. prof. dr hab. Krzysztof Konecki (5) 172395

(1) Dajerling Dominik (2) Czystość u Jana Pawła II i Karola Wojtyty na tle koncepcji wybranych autorów (3) prof. dr hab. Marian Grabowski (4) ks. dr Witold Dorsz (5) 186220

(1) Dankowski Przemysław (2) Kościół domowy w interpretacji Soboru Watykańskiego II (3) ks. prof. dr hab. Czesław Rychlicki (4) ks. dr hab. Krzysztof Krzemiński (5) 157452

(1) Doligalska Magdalena (2) Czułość w mitości (3) prof. dr hab. Marian Grabowski (4) ks. dr Witold Dorsz (5) 172409

(1) Doligalski Andrzej (2) Problematyka Krzyża w nauczaniu Cyryla Jerozolimskiego (3) ks. dr hab. Tomasz Kaczmarek (4) ks. prof. dr hab. Dariusz Zagórski (5) 162099

(1) Figurski Łukasz (2) Zbawczy charakter Objawienia Bożego na podstawie katechez środowych Jana Pawta II: „,Wierze w Jezusa Chrystusa Odkupiciela” 
(3) ks. prof. dr hab. Jan Perszon (4) ks. dr hab. Krzysztof Krzemiński (5) 172 406

(1) Filipiak Tomasz (2) Pochodzenie i natura władzy królewskiej w wybranych pismach św. Izydora $z$ Sewilli na tle literatury patrystycznej i antycznej (3) o. dr hab. Mieczysław Paczkowski (4) ks. prof. dr hab. Dariusz Zagórski (5) 186226

(1) Gościk Dawid (2) Soborowe nauczanie Kościoła na temat wolności religijnej $i$ jej podstaw na tle wybranych dokumentów państwowych i międzynarodowych (3) ks. prof. dr hab. Jan Perszon (4) ks. dr hab. Krzysztof Krzemiński (5) 198 774

(1) Jankowski Andrzej (2) Kapituly w kanonicznym prawie powszechnym i partykularnym toruńskim (3) ks. dr hab. Janusz Gręźlikowski (4) ks. dr hab. Wiesław Kraiński (5) 172418

(1) Jedwabski Piotr (2) Duszpasterskie wsparcie osób uzależnionych od alkoholu $w$ świetle wspótczesnej literatury teologiczno-pastoralnej (3) ks. dr Krzysztof Lewandowski (4) ks. prof. dr hab. Mirosław Mróz (5) 225940

(1) Kalicki Przemysław (2) Funkcje kapłanów wobec Księgi Prawa w czasach reformy Ezdrasza i Nehemiasza. Studium egzegetyczno-teologiczne Neh 8 (3) ks. dr Tomasz Tułodziecki (4) ks. prof. dr hab. Dariusz Kotecki (5) 172420

(1) Karpiński Błażej (2) Czynności poprzedzajace zawarcie małżeństwa w prawie kanonicznym i w prawie polskim (3) ks. dr hab. Janusz Gręźlikowski (4) ks. dr hab. Wiesław Kraiński (5) 186242

(1) Kempiński Przemysław (2) Przymiot nierozerwalności małzeństwa w prawie kanonicznym (3) ks. dr hab. Janusz Gręźlikowski (4) ks. dr hab. Wiesław Kraiński (5) 186244

(1) Kędzierski Jacek (2) Treści moralne Liturgii Mszy Świętej z Uroczystości Świętego Józefa Oblubieńca Najświętszej Maryi Panny (3) ks. dr hab. Jacek Szymański (4) ks. prof. dr hab. Krzysztof Konecki (5) 172424

(1) Kowalik Grzegorz (2) Parafia p.w. św. Mikołaja biskupa w Kruszynach (3) ks. prof. dr hab. Anastazy Nadolny (4) ks. dr hab. Witold Kujawski (5) 157476

(1) Kozik Joanna (2) Stużba życiu w opiece paliatywnej (3) ks. prof. dr hab. Jerzy Bagrowicz (4) dr hab. Beata Bilicka (5) 186251

(1) Kraśniewska Anna (2) Anioł w świetle literackiej twórczości ks. Jana Twardowskiego (3) ks. dr hab. Krzysztof Krzemiński (4) ks. prof. dr hab. Jan Perszon (5) 186252

(1) Krygier Michał (2) Aktualizacja kerygmatu czytań biblijnych Uroczystości Najświętszego Ciała i Krwi Chrystusa Roku B w kaznodziejstwie polskim w latach 1974-2006 (3) ks. prof. dr hab. Jerzy Bagrowicz (4) ks. prof. dr hab. Krzysztof Konecki (5) 172435

(1) Leszczyńska Anna (2) Miłość oblubieńcza jako kategoria zrozumienia relacji matżeńskich $w$ świetle „Mężczyzna i niewiasta stworzyl” ich Jana Pawła II (3) ks. prof. dr hab. Mirosław Mróz (4) ks. prof. dr hab. Ireneusz Werbiński (5) 186255 
(1) Lewicki Dawid (2) Prawa i obowiązi wiernych świeckich w prawie kanonicznym i diecezjalnym toruńskim (3) ks. dr hab. Janusz Gręźlikowski (4) ks. dr hab. Wiesław Kraiński (5) 172441

(1) Maciejko Paweł (2) Parafia p.w. świętych Piotra i Pawła w Lembargu (3) ks. prof. dr hab. Anastazy Nadolny (4) ks. dr hab. Witold Kujawski (5) 172445

(1) Maćkiewicz Sylwia (2) Wzory osobowe w katechezie polskiej po Soborze Watykańskim II (3) dr hab. Beata Bilicka (4) ks. prof. dr hab. Jerzy Bagrowicz (5) 186324

(1) Moskal Katarzyna (2) Motyw drzewa życia w Księdze Ezechiela 31, 3-9 w kontekście Księgi Rodzaju 2,4-3,16 (3) ks. dr Tomasz Tułodziecki (4) ks. prof. dr hab. Dariusz Kotecki (5) 186278

(1) Moskal Krzysztof (2) Parafia p.w. św. Marii Magdaleny w Kurzętniku (3) ks. prof. dr hab. Anastazy Nadolny (4) ks. dr hab. Witold Kujawski (5) 172457

(1) Niemiro Katarzyna (2) Wybór w miłości wedlug Karola Wojtyly i Maxa Schelera (3) prof. dr hab. Marian Grabowski (4) ks. dr Witold Dorsz (5) 186266

(1) Noch Adam (2) Światto wasze w Mt 5, 16, jako dar i wezwanie (3) ks. prof. dr hab. Waldemar Chrostowski (4) ks. prof. dr hab. Dariusz Kotecki (5) 198771

(1) Olewiecka Agnieszka (2) Okoliczności narodzin Jezusa Chrystusa w Mt 1,1825. Studium egzegetyczno-teologiczne (3) ks. prof. dr hab. Dariusz Kotecki (4) ks. dr Tomasz Tułodziecki (5) 186262

(1) Ołtuszewski Łukasz (2) Impotencja (kan. 1068 CIC/1917 oraz kan. 1084 KPK/1983) jako tytut prawny w procesach o stwierdzenie nieważności matżeństwa w świetle wyroków Biskupiego Sadu Duchownego w Gdańsku w latach 1976-1992 oraz Gdańskiego Trybunału Metropolitarnego w latach 19922004 (3) ks. dr hab. Wiesław Kraiński (4) ks. dr hab. Janusz Gręźlikowski (5) 209781

(1) Piasecki Paweł (2) Problematyka Listów Pasterskich Biskupów Włocławskich w latach 1987-2003 (3) ks. prof. dr hab. Jerzy Bagrowicz (4) ks. prof. dr hab. Krzysztof Konecki (5) 172471

(1) Porębna Aleksandra (2) Ubóstwo podejmowane z miłości do Chrystusa na przykładzie życia Matki Teresy z Kalkuty (3) ks. prof. dr hab. Ireneusz Werbiński (4) ks. prof. dr hab. Mirosław Mróz (5) 186285

(1) Potoczny Ireneusz (2) Maryja jako dar miłosierdzia Ojca wedtug Marie Dominique Philippe (3) ks. prof. dr hab. Jan Perszon (4) ks. dr hab. Krzysztof Krzemiński (5) 218480

(1) Prusakowska Monika (2) Rola miłości w ksztattowaniu osobowości dziecka $w$ wieku przedszkolnym $w$ rodzinie $w$ oparciu o literature przedmiotu (3) ks. prof. dr hab. Jerzy Bagrowicz (4) ks. dr hab. Zbigniew Zarembski (5) 186288

(1) Radojewska Agnieszka (2) Tajemnica Sacramentum Caritatis w życiu duchowym chrześcijanina w oparciu o dokumenty Kościoła na Rok Eucharystii (3) ks. dr hab. Krzysztof Krzemiński (4) ks. prof. dr hab. Jan Perszon (5) 186291

(1) Rataj-Sadowska Joanna (2) Wpływ schizofrenii na ważność małzeństwa $w$ świetle Kodeksu Prawa Kanonicznego (3) ks. dr hab. Janusz Gręźlikowski (4) ks. dr hab. Wiesław Kraiński (5) 186293 
(1) Recki Kazimierz (2) Przygotowanie do zawarcia sakramentu matżeństwa w prawie kanonicznym i diecezjalnym toruńskim (3) ks. dr hab. Janusz Gręźlikowski (4) ks. dr hab. Wiesław Kraiński (5) 172481

(1) Recki Tomasz (2) Kościót jako Mistyczne Ciało Chrystusa w świetle „Objaśnień Psalmów" św. Augustyna (3) ks. dr hab. Tomasz Kaczmarek (4) ks. prof. dr hab. Dariusz Zagórski (5) 172482

(1) Reich Pawel (2) Rozwój wiary religijnej młodzieży w wieku dorastania w Polsce po 1989 roku w świetle wspótczesnej literatury (3) ks. prof. dr hab. Jerzy Bagrowicz (4) dr hab. Beata Bilicka (5) 186362

(1) Rochman Paweł (2) Obraz Boga Edyty Stein na podstawie jej pism (3) ks. prof. dr hab. Czesław Rychlicki (4) ks. dr hab. Krzysztof Krzemiński (5) 187256

(1) Różycka Agnieszka (2) Wspótpraca rodziny i Kościoła w wychowaniu dziecka do wiary w oparciu o dokumenty nauki Kościoła katolickiego i literature (3) ks. prof. dr hab. Jerzy Bagrowicz (4) dr hab. Beata Bilicka (5) 186297

(1) Różyńska Sandra (2) Troska Kościoła o rozwiedzionych żyjacych w nowych zwiazkach. Studium pastoralne w świetle adhortacji apostolskiej Jana Pawta II ,Familiaris Consortio” (3) ks. dr hab. Zbigniew Zarembski (4) ks. prof. dr hab. Jerzy Bagrowicz (5) 186298

(1) Sadowski Bartosz (2) Zadania matżeństwa i rodziny w ewangelizacyjnej misji Kościoła (3) ks. prof. dr hab. Czesław Rychlicki (4) ks. dr hab. Krzysztof Krzemiński (5) 186365

(1) Schmelter Robert (2) Bractwo świętego Piusa X i jego status prawny w Kościele. Studium historyczno-kanoniczne (3) ks. dr hab. Janusz Gręźlikowski (4) ks. dr hab. Wiesław Kraiński (5) 186380

(1) Schodowska Ewelina (2) Konflikt między nauczycielem religii (katecheta) a uczniami - szansa czy zagrożenie? Praca w oparciu o literature pedagogiczna $i$ katechetyczna (3) ks. prof. dr hab. Jerzy Bagrowicz (4) dr hab. Beata Bilicka (5) 186300

(1) Skarżyński Łukasz (2) Wrażliwość pasterska św. Ambrożego z Mediolanu na problemy społeczne $w$ świetle pism ,O Nabocie” $i$,, O Tobiaszu” (3) ks. dr hab. Tomasz Kaczmarek (4) o. dr hab. Mieczysław Paczkowski (5) 172493

(1) Skowroński Tomasz (2) Pamiątka Pana w dokumentach Kościoła na Rok Eucharystii (październik 2004-październik 2005) (3) ks. dr hab. Daniel Brzeziński (4) ks. prof. dr hab. Krzysztof Konecki (5) 186301

(1) Sobociński Paweł (2) Postaci, wydarzenia i motywy biblijne jako figury Kościoła w Enarrationes in Psalmos św. Augustyna (3) ks. dr hab. Tomasz Kaczmarek (4) ks. prof. dr hab. Dariusz Zagórski (5) 172500

(1) Sporysz Weronika (2) Uzdrowienie niewidomego spod Jerycha (Mk 10, 4652). Analiza kontekstualna (3) ks. prof. dr hab. Dariusz Kotecki (4) ks. dr Tomasz Tułodziecki (5) 199386

(1) Szablewska Kamila (2) Sekty wyzwaniem duszpasterskim dla Kościoła na podstawie świadków Jehowy (3) ks. prof. dr hab. Jan Perszon (4) ks. dr Jacek Kędzierski (5) 172437

(1) Szczygłowska Jolanta (2) Uzależnienie od rodziców jako przyczyna psychicznej niezdolności do podjęcia istotnych obowiązów matżeńskich kan. 1095 n.3 
$K P K$ (3) ks. dr hab. Wiesław Kraiński (4) ks. dr hab. Janusz Gręźlikowski (5) 186306

(1) Szefler Augustyn (2) Kult łaskami stynacego Wizerunku Matki Bożej Lisewskiej (3) ks. dr hab. Daniel Brzeziński (4) ks. dr hab. Janusz Gręźlikowski (5) 157510

(1) Sztylka Łukasz (2) Duchowość kapłańska w świetle Dyrektorium o Postudze $i$ Życiu Kapłanów Kongregacji do Spraw Duchowieństwa (3) ks. prof. dr hab. Ireneusz Werbiński (4) ks. dr hab. Stanisław Suwiński (5) 172510

(1) Urbaniak Dawid (2) Homoseksualizm jako przyczyna niezdolności do podjęcia istotnych obowiazków małżeńskich - kan. $1095 \mathrm{nr} 3$ (3) ks. dr hab. Wiesław Kraiński (4) ks. dr hab. Janusz Gręźlikowski (5) 172523

(1) Walendziak Jarosław (2) Powołanie i posłannictwo wiernych świeckich $w$ świetle II Polskiego Synodu Plenarnego (1991-1999) (3) ks. dr hab. Janusz Gręźlikowski (4) ks. dr hab. Wiesław Kraiński (5) 186374

(1) Wiśniewski Marcin (2) Wybrane zagadnienia dotyczace grzechu przeciwko Duchowi Świętemu w literaturze patrystyczno-scholastycznej (3) ks. prof. dr hab. Mirosław Mróz (4) ks. prof. dr hab. Ireneusz Werbiński (5) 157522

(1) Witkowski Leszek (2) Kapłańskie Bractwo Świętego Piotra. Geneza. Liturgia (3) ks. dr hab. Daniel Brzeziński (4) ks. prof. dr hab. Krzysztof Konecki (5) 172532

(1) Witkowski Marcin (2) Doświadczenie krzyża na przykładzie Siostry Faustyny Kowalskiej (3) ks. prof. dr hab. Ireneusz Werbiński (4) ks. prof. dr hab. Mirosław Mróz (5) 157523

(1) Wolfram Marek (2) Gesu Cristo, l'unico Mediatore. Rivelazione e Storia della salvezza alla Luce del Simbolo della Fede (3) ks. prof. dr hab. Czesław Rychlicki (4) ks. prof. dr hab. Dariusz Kotecki (5) 226547

(1) Wrzos Anna (2) Urzeczywistnianie świętości na przyktadzie życia i dziet św. Urszuli Ledóchowskiej (3) ks. prof. dr hab. Ireneusz Werbiński (4) ks. prof. dr hab. Mirosław Mróz (5) 186330

(1) Zalewska Dorota (2) Koncepcja liturgii w myśli teologicznej Josepha Ratzingera (3) ks. prof. dr hab. Jan Perszon (4) ks. dr hab. Krzysztof Krzemiński (5) 172538

(1) Zawacki Mariusz (2) Środki dowodowe w procesie o stwierdzenie nieważności malżeństwa kościelnego wedtug Kodeksu Prawa Kanonicznego i Instrukcji „Dignitas connubi” (3) ks. dr hab. Janusz Gręźlikowski (4) ks. dr hab. Wiesław Kraiński (5) 172540

(1) Zawada Wiktor (2) Sakrament matzeństwa w świetle Katechizmu Kościoła Katolickiego (3) dr hab. Janusz Gręźlikowski (4) ks. dr hab. Wiesław Kraiński (5) 186382

(1) Zięba Katarzyna (2) Kościół a Żydzi w tradycji Janowej (3) ks. prof. dr hab. Dariusz Kotecki (4) ks. dr Tomasz Tułodziecki (5) 186332

(1) Żychski Damian (2) Zagadnienie madrości w świetle „,Summa Thelogiae” św. Tomasza z Akwinu (II-II, q. 45, a. 1-6) (3) ks. prof. dr hab. Mirosław Mróz (4) ks. prof. dr hab. Ireneusz Werbiński (5) 157530 
2009

(1) Antonkiewicz Mariusz (2) Matzeństwo i rodzina w świetle uchwat II Polskiego Synodu Plenarnego (3) ks. dr hab. Janusz Gręźlikowski (4) ks. dr hab. Wiesław Kraiński (5) 186335

(1) Barański Kamil (2) Świętość w świetle Konstytucji Zgromadzenia Stowa Bożego (3) ks. prof. dr hab. Ireneusz Werbiński (4) ks. prof. dr hab. Mirosław Mróz (5) 225561

(1) Bartczak Jacek (2) Ewangelizacja przez kulturę w świetle przemówień Jana Pawła II do świata nauki i kultury (3) ks. dr hab. Zbigniew Zarembski (4) ks. prof. dr hab. Dariusz Zagórski (5) 186336

(1) Bąkowska Justyna (2) Swiętość rodziny na podstawie wybranych artykułów pótrocznika ,, Studia nad Rodzina" (3) ks. prof. dr hab. Ireneusz Werbiński (4) ks. dr hab. Zbigniew Zarembski (5) 196881

(1) Chrostowski Marcin (2) Ostrzeżenie przed ,obca kobieta" w Prz 7 (3) ks. dr Tomasz Tułodziecki (4) ks. prof. dr hab. Dariusz Kotecki (5) 196834

(1) Ciechorski Łukasz (2) Wptyw baalizmu na ksztattowanie się wiary Izraela (3) ks. prof. dr hab. Jan Perszon (4) ks. dr Tomasz Tułodziecki (5) 196835

(1) Dobkowska Elwira (2) Kościót w Polsce wobec przemian społeczno-ustrojowych w Ojczyźnie po 1989 roku. Studium na podstawie listów pasterskich Episkopatu Polski (3) ks. dr hab. Wiesław Łużyński (4) ks. prof. dr hab. Mirosław Mróz (5) 196842

(1) Dobrzyńska-Pakowska Anna (2) Dzieje klasztoru benedyktynek w Grudziądzu (3) ks. prof. dr hab. Anastazy Nadolny (4) ks. dr hab. Wojciech Frątczak (5) 196843

(1) Drachal Marcin (2) Dzieje Domu Misyjnego św. Arnolda Janssena w Laskowicach 1958-2008 (3) ks. prof. dr hab. Anastazy Nadolny (4) ks. dr hab. Wojciech Frątczak (5) 196846

(1) Dziergawko Anna (2) Być synem w świetle Ga 4, $21-31$ (3) ks. dr Stanisław Jankowski (4) ks. bp prof. dr hab. Zbigniew Kiernikowski (5) 175436

(1) Filipska Katarzyna (2) Dynamizm miłości w pismach C.S. Lewisa (3) ks. prof. dr hab. Jan Perszon (4) ks. prof. dr hab. Mirosław Mróz (5) 196852

(1) Garncarek Marcin (2) Matżeństwo sakramentalne droga do świętości na przykładzie błogosławionej pary Luigiego i Marii Beltrame Quattrocchi (3) ks. prof. dr hab. Ireneusz Werbiński (4) ks. dr hab. Zbigniew Zarembski (5) 172 408

(1) Gerke Agnieszka (2) Aborcja zagrożeniem rodziny w świetle wybranych dokumentów nauczania Jana Pawła II (3) ks. prof. dr hab. Jerzy Bagrowicz (4) ks. dr hab. Zbigniew Zarembski (5) 196856

(1) Gronowska Lidia (2) Czystość przedmatżenska i jej znaczenie dla życia matżonków w świetle wspótczesnych dokumentów Kościoła (3) ks. prof. dr hab. Jerzy Bagrowicz (4) ks. dr hab. Zbigniew Zarembski (5) 196880

(1) Gulczyńska Katarzyna (2) Postać Piotra w świetle J 21, 1-25 (3) ks. prof. dr hab. Dariusz Kotecki (4) ks. dr Tomasz Tułodziecki (5) 196861 
(1) Gwiaździńska Aneta (2) Eklezjologia pneumatologiczna w katechezach Jana Pawła II „, O Duchu Świętym” (3) ks. prof. dr hab. Jan Perszon (4) ks. dr hab. Krzysztof Krzemiński (5) 196862

(1) Ichnowski Przemysław (2) Analiza interpretacji formuly Pawłowej „Utrzymanie ciała we czci” (1 TES4;4) w ,Mężczyzna i niewiasta stworzyt ich” Jana Pawta II (3) prof. dr hab. Marian Grabowski (4) ks. dr Witold Dorsz (5) 196 864

(1) Jażdżewska Małgorzata (2) Przyczyny nieważności małżeństwa $w$ świetle norm prawa kanonicznego (3) ks. dr hab. Janusz Gręźlikowski (4) ks. dr hab. Wiesław Kraiński (5) 196872

(1) Kajut Remigiusz (2) Ustrój i organizacja Diecezji Pelplińskiej w latach 19922007 (3) ks. prof. dr hab. Anastazy Nadolny (4) ks. dr hab. Wojciech Frątczak (5) 196875

(1) Kańkowski Marek (2) Bigamia w prawie polskim i prawie kanonicznym (3) ks. dr hab. Janusz Gręźlikowski (4) ks. dr hab. Wiesław Kraiński (5) 196878

(1) Kiełkowska Anna (2) Wpływ dialogu matżeńskiego na duchowość rodziny (3) ks. prof. dr hab. Ireneusz Werbiński (4) ks. dr hab. Zbigniew Zarembski (5) 186241

(1) Kociniewski Marcin (2) Porównanie koncepcji miłości Karola Wojtyły w „, Mitości i odpowiedzialności" z obrazem mitości Dietricha von Hildebranda w „Istocie mitości” (3) prof. dr hab. Marian Grabowski (4) ks. dr Witold Dorsz (5) 196887

(1) Komorowska Maria (2) Symbolika Wieczerzy wedtug Ap 3, 20 (3) o. dr Piotr Szymański (4) ks. prof. dr hab. Dariusz Kotecki (5) 233914

(1) Kozłowska Anna (2) Katedra Gotycka. Geneza, architektura, przestanie teologiczno-liturgiczne na przykładzie średniowiecznych katedr Francji (3) ks. dr hab. Daniel Brzeziński (4) ks. prof. dr hab. Dariusz Zagórski (5) 172431

(1) Kruszko Katarzyna (2) Miłość między mężczyzną i kobieta na podstawie katechez środowych Jana Pawta II „, Mężczyzna i niewiasta stworzyt ich” (3) ks. prof. dr hab. Jerzy Bagrowicz (4) ks. dr hab. Zbigniew Zarembski (5) 196894

(1) Krysztofowicz Jarosław (2) Kult Najświętszego Serca Pana Jezusa w Zgromadzeniu Braci Pocieszycieli z Getsemani (3) ks. dr hab. Wojciech Hanc (4) ks. dr hab. Zbigniew Zarembski (5) 186348

(1) Lesicki Sławomir (2) Misja Jezusa w Łk 12, 49-53. Studium egzegetyczno-teologiczne (3) ks. prof. dr hab. Dariusz Kotecki (4) ks. dr Tomasz Tułodziecki (5) 186351

(1) Lipińska Joanna (2) Matki Teresy chrześcijański ideał miłości w świetle „Deus caritas est” (3) ks. dr hab. Krzysztof Krzemiński (4) ks. prof. dr hab. Jan Perszon (5) 196902

(1) Lisecka Magdalena (2) Justus z Urgello. Komentarz do „Pieśni nad pieśnia$m i ”(3)$ o. dr hab. Mieczysław Paczkowski (4) ks. prof. dr hab. Dariusz Zagórski (5) 196904

(1) Marendziak Marcin (2) Antykoncepcja w świetle encykliki „Humanae vitae” (3) ks. dr hab. Jacek Szymański (4) ks. prof. dr hab. Mirosław Mróz (5) 186 354 
(1) Matczak Rafał (2) Troska Kościoła o dzieci z rodzin rozbitych. Studium pastoralne w świetle Dyrektorium Duszpasterstwa Rodzin (3) ks. dr hab. Zbigniew Zarembski (4) ks. prof. dr hab. Dariusz Zagórski (5) 186355

(1) Meszyński Łukasz (2) Ottarz w liturgii chrześcijańskiej. Geneza, prawodawstwo, teologia (3) ks. dr hab. Daniel Brzeziński (4) ks. prof. dr hab. Krzysztof Konecki (5) 186356

(1) Mikuszewski Paweł (2) Usprawiedliwienie przez wiarę podstawą misji wśród pogan w świetle Listu św. Pawta do Galatów (3) ks. bp prof. dr hab. Zbigniew Kiernikowski (4) ks. prof. dr hab. Dariusz Kotecki (5) 233885

(1) Nykiel Mirosław (2) Malżeństwa mieszane jako problem prawno-duszpasterski w świetle polskiej literatury teologicznej (3) ks. prof. dr hab. Jan Perszon (4) ks. dr hab. Janusz Gręźlikowski (5) 196919

(1) Olik Agnieszka (2) Przygotowanie do matżeństwa i życia w rodzinie w wybranych podręcznikach do nauki religii dla szkót ponadgimnazjalnych (3) dr hab. Beata Bilicka (4) ks. prof. dr hab. Jerzy Bagrowicz (5) 196921

(1) Osiński Paweł (2) Formacja sumienia dziecka $w$ wieku szkolnym $w$ świetle encykliki ,,Veritatis splendor” (3) ks. dr hab. Jacek Szymański (4) ks. prof. dr hab. Mirosław Mróz (5) 186357

(1) Petrykowski Jacek (2) Jezus jako Pasterz. Studium egzegetyczno-teologiczne $J$ 10, 1-21 (3) prof. dr hab. Dariusz Kotecki (4) ks. dr Tomasz Tułodziecki (5) 196924

(1) Piechota Milen (2) Stużebny charakter władzy w nauczaniu społecznym Kościoła (3) ks. dr hab. Wiesław Łużyński (4) ks. prof. dr hab. Mirosław Mróz (5) 186279

(1) Prot Danuta (2) Próba antropologicznej analizy przyjaźni (3) prof. dr hab. Marian Grabowski (4) ks. prof. dr hab. Dariusz Kotecki (5) 172475

(1) Radziejewski Grzegorz (2) Aborcja w świetle przepisów prawa polskiego $i$ prawa kanonicznego (3) ks. dr hab. Janusz Gręźlikowski (4) ks. dr hab. Wiesław Kraiński (5) 186360

(1) Rafalski Karol (2) Naśladowanie Chrystusa jako podstawowa kategoria moralności chrześcijańskiej na podstawie dziet Dietricha Bonhoeffera (3) ks. prof. dr hab. Mirosław Mróz (4) ks. prof. dr hab. Ireneusz Werbiński (5) 186 361

(1) Rogozińska Daria (2) Człowiek wobec śmierci oraz wiara $w$ życie wieczne $w$ świetle inskrypcji nagrobnych na cmentarzu parafialnym we Wrześni (3) ks. prof. dr hab. Jan Perszon (4) ks. prof. dr hab. Mirosław Mróz (5) 196932

(1) Sadłos Paulina (2) Zespół ADHD jako wspótczesne wyzwanie dla duszpasterskiej działalności Kościoła. Studium w świetle literatury teologiczno-pastoralnej (3) ks. dr hab. Zbigniew Zarembski (4) ks. prof. dr hab. Ireneusz Werbiński (5) 196943

(1) Słupecka Agnieszka (2) Czy życie bez Boga jest możliwe? Zagadnienie wiary w twórczości Tadeusza Różewicza (3) ks. prof. dr hab. Jan Perszon (4) ks. dr hab. Krzysztof Krzemiński (5) 206548

(1) Szczepaniak Paweł (2) Szaty i oznaki w stużbie liturgii Kościoła (3) ks. prof. dr hab. Krzysztof Konecki (4) ks. dr hab. Daniel Brzeziński (5) 186368 
(1) Szczepaniak Regina (2) Strumienie wody żywej. Studium egzegetyczno-teologiczne J 7, 37 - 39 (3) ks. prof. dr hab. Dariusz Kotecki (4) ks. dr Tomasz Tułodziecki (5) 196946

(1) Szoszorek Julita (2) Cierpienie $w$ życiu duchowym czlowieka $w$ świetle pism księdza Waltera Ciszka (3) ks. prof. dr hab. Ireneusz Werbiński (4) ks. dr hab. Zbigniew Zarembski (5) 196949

(1) Szukiel Aneta (2) Zawarcie małzeństwa per procuram w prawie kanonicznym i polskim (3) ks. dr hab. Janusz Gręźlikowski (4) ks. dr hab. Wiesław Kraiński (5) 186308

(1) Szuszkiewicz Aleksandra (2) Rola wstydu seksualnego w koncepcji Maxa Schelera, Karola Wojtyty i Jana Pawta II (3) prof. dr hab. Marian Grabowski (4) ks. dr Witold Dorsz (5) 186310

(1) Szymański Robert (2) Komputer jako narzędzie multimediów w katechezie $w$ świetle dokumentów Magisterium Kościoła i literatury przedmiotu (3) ks. prof. dr hab. Jerzy Bagrowicz (4) dr hab. Beata Bilicka (5) 186311

(1) Troka Anna (2) Parafia Zwiastowania Najświętszej Maryi Panny w Chojnicach 1975-2004 (3) ks. prof. dr hab. Anastazy Nadolny (4) ks. dr hab. Witold Kujawski (5) 196952

(1) Turek Agnieszka (2) Walka ze złymi myślami w duchowości starożytnego monastycyzmu na przyktadzie Ewagriusza z Pontu (3) o. dr hab. Mieczysław Paczkowski (4) ks. prof. dr hab. Dariusz Zagórski (5) 196953

(1) Turzyńska Barbara (2) Akceptacja nauki Kościoła o matżeństwie i rodzinie $w$ procesie bliższego przygotowania narzeczonych do matżeństwa $w$ świetle badań wtasnych (3) o. dr Borys Soiński (4) ks. prof. dr hab. Jan Perszon (5) 196954

(1) Wadych Bogumiła (2) Biskup Zygfryd Ignacy Kowalski (1910-1995) (3) ks. prof. dr hab. Anastazy Nadolny (4) ks. dr hab. Wojciech Frątczak (5) 196956

(1) Warmiński Przemysław (2) Dzieje dekanatu włocławskiego w latach 19171925 (3) ks. dr hab. Witold Kujawski (4) ks. dr hab. Wojciech Frątczak (5) 186376

(1) Wasielewski Łukasz (2) Szczęśliwy człowiek, który stuży Panu (Ps 128 (127),1). Analiza teologiczno-liturgiczna tekstów Mszy św. wspomnienia św. Józefa Rzemieślnika (3) ks. prof. dr hab. Krzysztof Konecki (4) ks. dr hab. Daniel Brzeziński (5) 186377

(1) Wawrzyniak Olga (2) Rozłączenie matżonków w świetle norm przepisów prawa kanonicznego (3) ks. dr hab. Janusz Gręźlikowski (4) ks. dr hab. Wiesław Kraiński (5) 196957

(1) Wenta Joanna (2) Parafia p.w. św. Marcina w Starej Kiszewie w latach 19452005 (3) ks. prof. dr hab. Anastazy Nadolny (4) ks. dr hab. Wojciech Frątczak (5) 196958

(1) Witkowska Agnieszka (2) Ponowoczesne przemiany religijności chrześcijańskiej. Analiza zjawiska w oparciu o wybrana literature przedmiotu (3) ks. prof. dr hab. Jan Perszon (4) ks. dr hab. Krzysztof Krzemiński (5) 186325 
(1) Włoch Emilia (2) Funkcje i zadania zespołów wokalnych w odnowionej liturgii po Soborze Watykańskim II (3) ks. dr Mariusz Klimek (4) ks. prof. dr hab. Jerzy Bagrowicz (5) 196962

(1) Woś Sylwia (2) Wiara w Jedynego Boga a wplywy pogańskie. Analiza egzege-

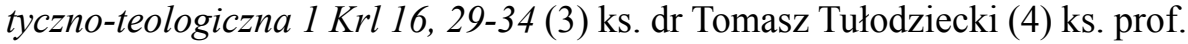
dr hab. Dariusz Kotecki (5) 196965

(1) Zielińska Dorota (2) Nadzieja jako próba przezwyciężenia nihilizmu-choroby wspótczesności. W świetle encykliki Benedykta XVI „Spe salvi” (3) ks. prof. dr hab. Jerzy Bagrowicz (4) ks. dr hab. Zbigniew Zarembski (5) 196831

2010

(1) Banach Marcin (2) Bunt Absaloma jako reakcja na brak sprawiedliwości króla. Studium egzegetyczno-teologiczne 2Sm 15,1-12 (3) ks. dr Tomasz Tułodziecki (4) ks. prof. dr hab. Dariusz Kotecki (5) 196826

(1) Bernat Iwona (2) Cnoty Maryi w świetle „, Redemptoris Mater" Jana Pawła II (3) ks. prof. dr hab. Mirosław Mróz (4) ks. prof. dr hab. Ireneusz Werbiński (5) 206541

(1) Bilicka Joanna (2) Hedonizm jako zagrożenie dla osobowego wymiaru seksualności człowieka w świetle encykliki „Humanae vitae” Pawta VI (3) ks. prof. dr hab. Jerzy Bagrowicz (4) ks. dr hab. Zbigniew Zarembski (5) 186208

(1) Birecka Katarzyna (2) Sytuacja prawna osób żyjacych w zwiazkach niesakramentalnych w ustawodawstwie i nauczaniu Jana Pawła II (3) ks. dr hab. Janusz Gręźlikowski (4) ks. dr hab. Wiesław Kraiński (5) 186210

(1) Brauer Dawid (2) Święty Augustyn w nauczaniu papieża Benedykta XVI (3) ks. dr hab. Tomasz Kaczmarek (4) ks. prof. dr hab. Dariusz Zagórski (5) 196830

(1) Ciechorski Jakub (2) Saul u Wróżki z Endor. Studium egzegetyczno-teologiczne $1 S M$ 28, 3-25 (3) ks. dr Tomasz Tułodziecki (4) ks. prof. dr hab. Dariusz Kotecki (5) 206534

(1) Dobry Marta (2) Trud i radość sakramentu pokuty w świetle „Reconciliatio et paenitentia" Jana Pawła II (3) ks. prof. dr hab. Jan Perszon (4) ks. dr hab. Zbigniew Wanat (5) 206535

(1) Domański Marcin (2) Największe przykazanie. Analiza egzegetyczna Mk 12, 28-34 (3) ks. prof. dr hab. Dariusz Kotecki (4) ks. dr Tomasz Tułodziecki (5) 196845

(1) Fiałkowski Bartosz (2) Powołanie mężczyzny wedtug wspótczesnego Magisterium Ecclesiae (3) ks. dr hab. Krzysztof Krzemiński (4) ks. prof. dr hab. Jan Perszon (5) 196850

(1) Fischer Tomasz (2) Nauczanie religii w świetle aktualnych przepisów prawa państwowego i kanonicznego (3) ks. dr hab. Janusz Gręźlikowski (4) ks. dr hab. Wiesław Kraiński (5) 196853

(1) Furman Marcin (2) Postuga kaptańska i życie konsekrowane w świetle Uchwat II Synodu Plenarnego (3) ks. dr hab. Janusz Gręźlikowski (4) ks. dr hab. Wiesław Kraiński (5) 196855 
(1) Gdaniec Karolina (2) Niezdolność do podjęcia istotnych obowiązków matżeńskich z powodu homoseksualizmu na tle katolickiego modelu matżeństwa (3) ks. dr Stanisław Cierkowski (4) ks. dr hab. Janusz Gręźlikowski (5) 199436

(1) Grabiasz Łukasz (2) Wartość ludzkiej pracy w świetle encykliki Ojca Świętego Jana Pawta II „Laborem exercens” (3) ks. dr Artur Niemira (4) ks. dr hab. Wiesław Łużyński (5) 196859

(1) Graś Paulina (2) Etyczne aspekty zapłodnienia in vitro $w$ świetle dokumentów Kościoła i wspótczesnej literatury (3) ks. prof. dr hab. Jerzy Bagrowicz (4) ks. dr hab. Zbigniew Zarembski (5) 199438

(1) Groszewska Monika (2) Cudotwórcze dziatanie Jezusa $w$ świetle perykopy o wskrzeszeniu Łazarza J 11, 1-45 (3) ks. prof. dr hab. Waldemar Chrostowski (4) ks. prof. dr hab. Dariusz Kotecki (5) 199440

(1) Jabłoński Jacek (2) Przepowiadanie Słowa Bożego w świetle Uchwat Drugiego Synodu Diecezji Włocławskiej z 1994 roku (3) ks. dr hab. Janusz Gręźlikowski (4) ks. dr hab. Wiesław Kraiński (5) 196865

(1) Jankowiak Tomasz (2) Cnota postuszeństwa droga naśladowania Chrystusa w świetle Konstytucji Zgromadzenia Braci Pocieszycieli z Getsemani (3) ks. dr Artur Niemira (4) ks. prof. dr hab. Mirosław Mróz (5) 196867

(1) Jankowski Andrzej (2) Status prawny Kościoła Katolickiego w świetle Ustawy o stosunku Państwa do Kościoła Katolickiego z 17 maja 1989 roku (3) ks. dr hab. Janusz Gręźlikowski (4) ks. dr hab. Wiesław Kraiński (5) 196868

(1) Kałużna Anna (2) Modlitwa, jałmużna i post w Homiliach na Ewangelię św. Mateusza Jana Chryzostoma (3) ks. prof. dr hab. Dariusz Zagórski (4) o. dr hab. Mieczysław Paczkowski (5) 206558

(1) Kania Marcin (2) Powolanie do życia w Chrystusie w świetle „Expositio in Epistolam S. Pauli ad Colossenses" św. Tomasza z Akwinu. Elementy chrystianologii moralnej (3) ks. prof. dr hab. Mirosław Mróz (4) ks. prof. dr hab. Ireneusz Werbiński (5) 196877

(1) Kołatka Paweł (2) Batwochwalstwo Gedeona. Studium egzegetyczno-teologiczne na podstawie Sdz 8, 22-27 (3) ks. dr Tomasz Tułodziecki (4) ks. prof. dr hab. Dariusz Kotecki (5) 196888

(1) Kosierb Artur (2) Pomoc pastoralna osobom uzależnionym od narkotyków $w$ świetle dokumentu Papieskiej Rady ds. Duszpasterstwa Zdrowia. Kościót, Narkotyki, Narkomania. Poradnik Duszpasterski (3) ks. dr hab. Zbigniew Zarembski (4) ks. prof. dr hab. Jerzy Bagrowicz (5) 196890

(1) Kreczman Rafał (2) Człowiek powołany do wspólnoty z Bogiem. Antropologia teologiczna dokumentów II Polskiego Synodu Plenarnego (1991-1999) (3) ks. dr hab. Krzysztof Krzemiński (4) ks. prof. dr hab. Jan Perszon (5) 186346

(1) Kuczkowska Marta (2) Zwyczaje i obrzędy weselne wśród mieszkańców parafii p.w. św. Anny w Skrwilnie (3) ks. prof. dr hab. Jan Perszon (4) ks. dr hab. Wiesław Łużyński (5) 206543

(1) Lewandowski Marcin (2) Eros i agape jako wymiary ludzkiej miłości w świetle encykliki „Deus caritas est” (3) ks. dr Artur Niemira (4) ks. prof. dr hab. Mirosław Mróz (5) 196901 
(1) Luda Kinga (2) Zwyczaje i obrzędy czasu wielkiego postu i Wielkanocy wśród mieszkańców parafii pw. św. Katarzyny Aleksandryjskiej w Grzywnie (3) ks. prof. dr hab. Jan Perszon (4) ks. dr hab. Daniel Brzeziński (5) 199443

(1) Marciniak Błażej (2) Nieważność wyroku w prawie matzeńskim w świetle Kodeksu Prawa Kanonicznego oraz instrukcji procesowej ,,Dignitas Connubii” (3) ks. dr hab. Wiesław Kraiński (4) ks. dr hab. Janusz Gręźlikowski (5) 196 911

(1) Mazzoll Elżbieta (2) Wielu jest powołanych, mało wybranych. Studium egzegetyczno-teologiczne Mt 22, 1-14 (3) ks. prof. dr hab. Dariusz Kotecki (4) ks. dr Tomasz Tułodziecki (5) 196927

(1) Melkowska Anna (2) Nadzwyczajny szafarz Komunii świętej w świetle Kodeksu Prawa Kanonicznego i norm prawnych w Kościele (3) ks. dr hab. Wiesław Kraiński (4) ks. dr hab. Janusz Gręźlikowski (5) 199433

(1) Nowacki Mariusz (2) Formacja do celibatu w świetle adhortacji „Pastores dabo vobis” (3) ks. dr hab. Jacek Szymański (4) ks. prof. dr hab. Mirosław Mróz (5) 196917

(1) Nowak Katarzyna (2) Wptyw patologii osobowości na zdolność do zawarcia małzeństwa w świetle przepisów prawa kanonicznego (3) ks. dr hab. Wiesław Kraiński (4) ks. dr hab. Janusz Gręźlikowski (5) 196918

(1) Ochotny Piotr (2) Prawda a postmodernizm ws świetle encykliki ,Fides et ratio” (3) ks. dr hab. Jacek Szymański (4) ks. prof. dr hab. Mirosław Mróz (5) 196920

(1) Pawlak Maciej (2) Eucharystia w świetle Uchwat Drugiego Synodu Diecezji Włocławskiej z 1994 roku (3) ks. dr hab. Janusz Gręźlikowski (4) ks. dr hab. Wiesław Kraiński (5) 196923

(1) Pilarz Krzysztof (2) Pneumatologia qumrańska (3) ks. dr Tomasz Tułodziecki (4) ks. prof. dr hab. Dariusz Kotecki (5) 186281

(1) Przybylski Marcin (2) Tytuł ,syn człowieczy” w Księdze Ezechiela na podstawie Ez 2,1-3,11 (3) ks. dr Tomasz Tułodziecki (4) ks. prof. dr hab. Dariusz Kotecki (5) 199456

(1) Pszczoła Łukasz (2) Świadomość młodzieży na temat sekt destrukcyjnych $i$ nowych ruchów religijnych działajacych $w$ Polsce i na świecie (3) ks. prof. dr hab. Jan Perszon (4) ks. dr hab. Zbigniew Zarembski (5) 199457

(1) Pukalski Dariusz (2) Status prawny Mszy Świętej według klasycznej formy rytu rzymskiego (3) ks. dr Stanisław Cierkowski (4) ks. dr hab. Janusz Gręźlikowski (5) 196928

(1) Reich Mira (2) Kapłaństwo kobiet w świetle dokumentów Episkopatu USA (3) ks. prof. dr hab. Jan Perszon (4) ks. dr hab. Krzysztof Krzemiński (5) 199445

(1) Relidziński Arkadiusz (2) Utrwalić imię zmarłego Prawo go'el na podstawie Rt 4, 1-12 (3) ks. dr Tomasz Tułodziecki (4) ks. prof. dr hab. Dariusz Kotecki (5) 196930

(1) Rogozińska Magdalena (2) Cudotwórcza moc Jezusa Chrystusa w świetle perykopy o wskrzeszeniu Łazarza. Studium egzegetyczno-teologiczne J 11, 1-44 (3) prof. dr hab. Dariusz Kotecki (4) ks. dr Tomasz Tułodziecki (5) 196933 
(1) Skrobicki Karol (2) Niezdolność do podjęcia obowiązów matżeńskich w wyrokach Sadu Kościelnego we Włocławku w latach 1995-2000 (3) ks. dr hab. Janusz Gręźlikowski (4) ks. dr hab. Wiesław Kraiński (5) 196939

(1) Smoliński Tomasz (2) Tytuły nieważności matżeństwa wedlug wyroków Sąu Kościelnego we Włocławku w latach 1995-2000 (3) ks. dr hab. Janusz Gręźlikowski (4) ks. dr hab. Wiesław Kraiński (5) 196940

(1) Springmann Katarzyna (2) Katecheza przygotowania do sakramentów wtajemniczenia chrześcijańskiego: pokuty $i$ Eucharystii uczniów z niepetnosprawnościa intelektualna w stopniu umiarkowanym (3) ks. prof. dr hab. Jerzy Bagrowicz (4) dr hab. Beata Bilicka (5) 206530

(1) Szczepańska Agnieszka (2) Cena i Owoce usprawiedliwienia w świetle 2 Kor 5, 21 (3) ks. bp prof. dr hab. Zbigniew Kiernikowski (4) ks. prof. dr hab. Dariusz Kotecki (5) 196947

(1) Szpejnowska Anna (2) Wiara Abrahama. Studium egzegetyczno-teologiczne na podstawie Rdz 22, 1-14 (3) ks. dr Tomasz Tułodziecki (4) ks. prof. dr hab. Dariusz Kotecki (5) 186307

(1) Śliwińska Sylwia (2) Dojrzewanie do ojcostwa w kontekście wspótczesnego kryzysu męskości (3) ks. prof. dr hab. Jan Perszon (4) ks. prof. dr hab. Ireneusz Werbiński (5) 206557

(1) Wadych Katarzyna (2) Dzieje parafii pw. Chrystusa Króla w Świeciu - Przechowie (1937-2009) (3) ks. prof. dr hab. Anastazy Nadolny (4) ks. prof. dr hab. Dariusz Zagórski (5) 199469

(1) Wantoch-Rekowska Agata (2) Rola modlitwy w życiu duchowym Matki Teresy $z$ Kalkuty (3) ks. prof. dr hab. Ireneusz Werbiński (4) ks. prof. dr hab. Jan Perszon (5) 206542

(1) Wnykowski Arkadiusz (2) Powołanie do życia matżeńsko-rodzinnego w nauczaniu Kościoła po Soborze Watykańskim II (3) ks. dr hab. Zbigniew Zarembski (4) ks. prof. dr hab. Ireneusz Werbiński (5) 199472

(1) Wróblewski Robert (2) Bractwo Świętych Aniołów Stróżów w Lubawie w latach 1798-1949 (3) ks. prof. dr hab. Anastazy Nadolny (4) ks. prof. dr hab. Dariusz Zagórski (5) 186329

(1) Zdziebłowska Anna (2) Potęga miłości (8,5b-7) jako klucz interpretacyjny do Pieśni na Pieśniami (3) ks. dr Tomasz Tułodziecki (4) ks. prof. dr hab. Dariusz Kotecki (5) 199471

(1) Ziółkowska Katarzyna (2) Świętość kobiety na przykładzie Teresy z Avila (3) ks. prof. dr hab. Ireneusz Werbiński (4) ks. prof. dr hab. Mirosław Mróz (5) 199478

(1) Zygmunt Mariusz (2) System finansowania instytucji kościelnych $w$ Polsce (3) ks. dr hab. Wiesław Kraiński (4) ks. dr hab. Janusz Gręźlikowski (5) 206561 


\section{BIBLIOGRAFIA}

Uchwała nr 20 Senatu Uniwersytetu Mikołaja Kopernika w Toruniu z dnia 19 grudnia 2000 roku w sprawie utworzenia Wydziału Teologicznego oraz kierunku studiów „teologia”, „Biuletyn Prawny UMK”, nr 8 z dnia 28 grudnia 2000 r. (http://www. umk.pl/uczelnia/dokumenty/biuletyn/prawo/?akcja=dokument\&typ=Uchwaly\&n$\mathrm{r}=20 \& \mathrm{bp}=8 \& \mathrm{rok}=2000$

Przepisy kancelaryjno-archiwalne, oprac. H. Duczkowska-Moraczewska, H. Robótka, Toruń 2004, ss. 116.

Zarządzenie nr 75 Rektora Uniwersytetu Mikołaja Kopernika w Toruniu, z dnia 30 maja 2012 r. w sprawie udostępniania i korzystania z zasobu Archiwum UMK, http://archiwum.umk.pl/zasob/regulamin/Z_Rektora_75_2012.pdf

Garszczyńska B., Bibliografia prac magisterskich, doktorskich i habilitacyjnych Wydziału Humanistycznego UMK związanych z tematyką pomorską (1945-marzec 1967), „Rocznik Toruński”, 2 (1967) s. 193-221.

Garszczyńska B., Bibliografia prac magisterskich, doktorskich i habilitacyjnych Wydziału Biologii i Nauk o Ziemi (Geografia) UMK związanych z tematyką pomorską (19451967), „Rocznik Toruński”, 3 (1969) s. 187-206.

Katalog prac magisterskich i licencjackich absolwentów archiwistyki w Toruniu z lat 1951-2010, oprac. H. Duczkowska-Moraczewska, E. Talarczyk, E. Wiśniewska, w: Dorobek naukowy i dydaktyczny toruńskiego ośrodka archiwistyki, red. H. Robótka, Toruń 2011, s. 317-477.

Moraczewska H., Bibliografia prac związanych z tematyką pomorską powstałych na Wydziale Humanistycznym w latach 1967-1972, „Rocznik Toruński”, 9 (1974), s. 289312.

Moraczewska H., Talarczyk E. [Wiśniewska], Bibliografia prac magisterskich, doktorskich i habilitacyjnych Wydziału Biologii i Nauk o Ziemi (Biologia) za lata 19451978, „Acta Universitatis Nicolai Copernici. Nauki Matematyczno-Przyrodnicze. Biologia”, z. 23, 1980, s. 91-206.

Moraczewska H., Talarczyk E. [Wiśniewska], Bibliografia prac magisterskich, doktorskich i habilitacyjnych Wydziału Biologii i Nauk o Ziemi (Geografia) za lata 19481980, „Acta Universitatis Nicolai Copernici. Nauki Matematyczno-Przyrodnicze. Geografia”, z. 17, 1982, s. 161-229.

Wencel-Kalembkowa U., Prace magisterskie napisane pod kierunkiem pracowników Katedry Historii Polski i Powszechnej XIX i XX w. UMK, „Zeszyty Naukowe UMK. Historia", 7 (1972) s. 119-142.

Słowa kluczowe: katalog, pomoc archiwalna, praca dyplomowa, praca magisterska, praca licencjacka, Wydział Teologiczny, Uniwersytet Mikołaja Kopernika, Archiwum UMK, archiwum, baza USOSweb 


\title{
THE CATALOGUE OF BACHELOR'S AND MASTER'S THESES AT THE FACULTY OF THEOLOGY OF NICOLAUS COPERNICUS UNIVERSITY IN TORUŃ IN THE YEARS 2001-2010
}

\begin{abstract}
Summary
The article contains a list of bachelor's and master's theses at the Faculty of Theology of Nicolaus Copernicus University stored in the University Archive. The list covers the years 2001-2010. The theses are arranged in chronological and alphabetical order by the annual date of the final exam and the name of author's work in a given year. The information included in the catalogue comes from the UsosWeb system. Additionally, this article presents the tables; the first one contains data on the number of graduated students along with their supervisors, and the other one the number of the written works in different years. As the catalogue is an archival aid, the author also included currently valid rules for the use of theses in the Archive of Nicolaus Copernicus University.
\end{abstract}

Keywords: catalogue, archival aid, thesis, master's thesis, bachelor's thesis, the Faculty of Theology, Nicolaus Copernicus University, the Archive of Nicolaus Copernicus University, archive, the USOSweb system 